\title{
Analytical Chemistry in Brazil: Healthy and Growing
}

\author{
Fábio R. P. Rocha, ${ }^{a}$ Edenir R. Pereira-Filho ${ }^{b}$ and Joaquim A. Nóbrega ${ }^{* b}$ \\ ${ }^{a}$ Instituto de Química, Universidade de São Paulo, 05513-970 São Paulo-SP, Brazil \\ ${ }^{b}$ Departamento de Química, Universidade Federal de São Carlos, CP 676, \\ 13560-970 São Carlos-SP, Brazil
}

\begin{abstract}
A química brasileira está crescendo rapidamente, sendo um dos principais alicerces para o contínuo desenvolvimento do país. Inspirados no $15^{\circ}$ Encontro Nacional de Química Analítica, ENQA, com um número recorde de participantes e comunicações, decidiu-se revisar os recentes desenvolvimentos em química analítica no Brasil. Foram escolhidas as mesmas áreas de aplicação adotadas para a organização temática do ENQA e selecionados artigos publicados por autores brasileiros em 7 periódicos de ampla penetração na área. Os dois periódicos científicos editados pela Sociedade Brasileira de Química também foram pesquisados. Esta revisão não é exaustiva, porém os trabalhos selecionados após 2008 mostram uma significativa visão geral da área. Pode-se concluir que a química analítica brasileira está saudável, em crescimento e certamente atenderá as demandas do país como uma potência emergida.
\end{abstract}

Chemical sciences in Brazil are growing fast and being one of the main supports for the continuous development of the country. Inspired on the $15^{\text {th }}$ Brazilian Meeting on Analytical Chemistry, ENQA, with a record number of participants and communications, we have decided to review recent developments in analytical chemistry in Brazil. We have chosen the same application areas used for the thematic organization of the ENQA and have searched papers published by Brazilian authors in 7 major and general journals in analytical chemistry. The two scientific journals published by the Brazilian Chemical Society were also searched. This review is not comprehensive, but the selected papers published after 2008 shown an impressive overview of the area. We may conclude that analytical chemistry is healthy and growing in Brazilian scenario and certainly will attend the demands of Brazil as an emerged power.

Keywords: food analysis, material analysis, pharmaceutical analysis, environmental analysis, chemometry, instrumentation, biological materials, fuels, Analytical Chemistry, Brazil

\section{Introduction}

The goal of this review is to highlight selected papers in several application areas to illustrate the fast and continuous development of analytical chemistry in Brazil. This evolution was discussed in two recent review papers, ${ }^{1,2}$ so the focus was to search papers published after 2007. The authors have not tried to be comprehensive. They selected the following journals for glancing recent developments: Journal of the Brazilian Chemical Society, Química Nova, The Analyst, Analytical and Bioanalytical Chemistry, Analytical Chemistry, Analytica Chimica Acta, Analytical Letters, Microchemical Journal, and Talanta. The goal was to work with journals with a general scope and also

*e-mail: djan@terra.com.br with journals edited by the Brazilian Chemical Society, SBQ. Some relevant recent reviews s $^{3,4}$ and application ${ }^{5-11}$ papers dealing with instrumentation, environmental and food control were not discussed here because they were published before the period searched. The selected papers were organized according to the main area investigated based on either the type of sample or the focus in instrumentation or chemometrics. The articles have at least one Brazilian author, but almost all of them were published by Brazilians working at Brazilian institutions. The Web of Science was searched to check the number of papers in 2008-2009 using the keywords: analytical chemistry, fuel or biodiesel, environmental or soil or water or atmosphere, food, instrumentation, chemometrics, pharmaceutical or drug, biological materials, and materials. The output was combined in Figure 1a. Afterwards, the same keywords were employed 
but the search was restricted to the journals above cited (Figure 1b). It can be seen that there is a correlation between the percentage of papers published in those topics when searching either all journals or the selected ones. It means that the selected journals properly represent the area and they cover $29 \%$ of all published papers according to the chosen keywords. The number of papers published by Brazilian researchers in chemistry and in analytical chemistry is shown in Figure 2 and it is impressive the growth of analytical chemistry area during this decade. The following topics will discuss selected papers highlighting their contribution to the analytical sciences.
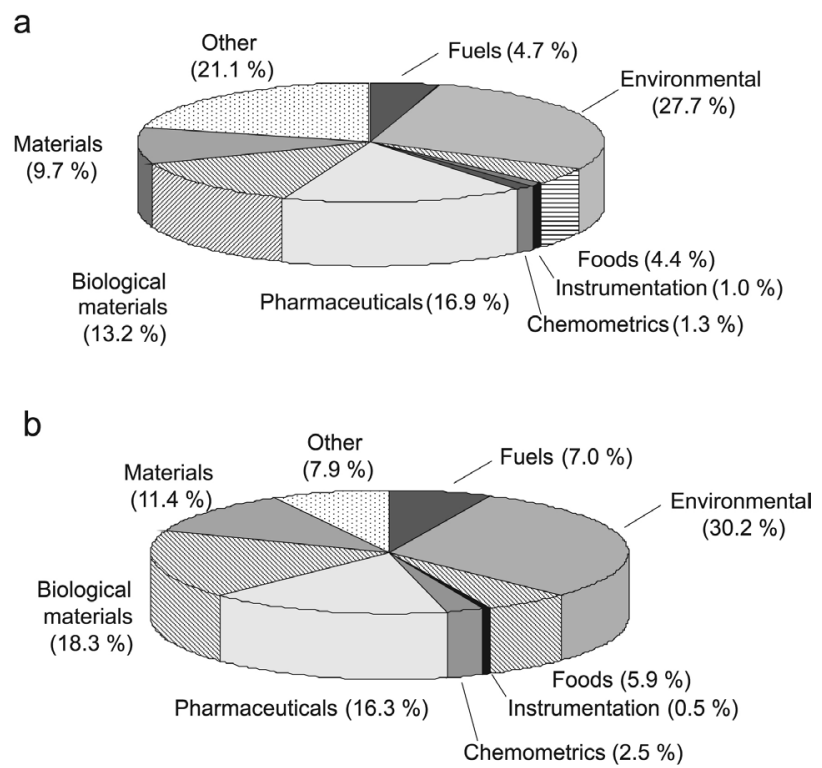

Figure 1. (a) Papers published in the selected topics according to the Web of Science database. (b) Papers published in the selected topics and selected journals.

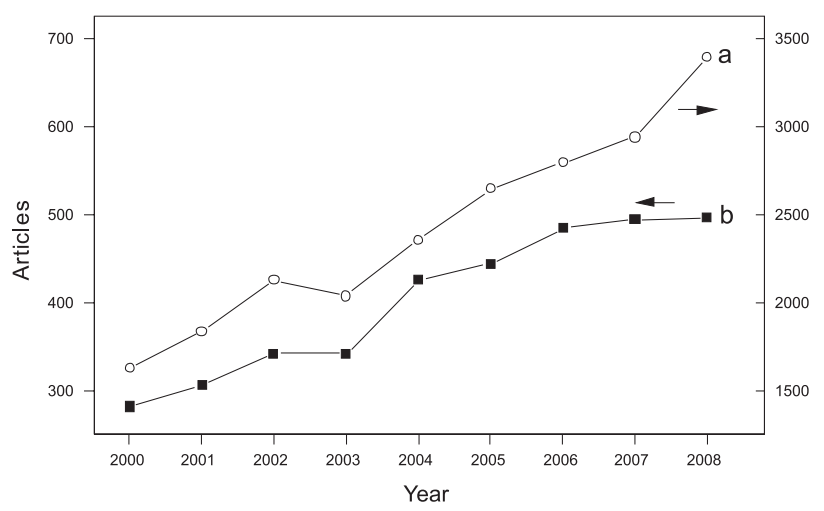

Figure 2. Number of papers published by Brazilian authors in chemistry (a) and in analytical chemistry (b) during 2000-2008.

\section{Biological Materials}

The development of new and innovative strategies for sample preparation is a well-established research area in
Brazil. One of the main focuses is related to the advance of microwave-assisted procedures aiming inorganic analysis. In this context an outstanding contribution dealt with the proposal of microwave-induced combustion, MIC, for fast and effective sample digestion. ${ }^{12}$ Barin et al. ${ }^{13}$ have extended the capability of this system by coupling MIC and flame furnace atomic absorption spectrometry (FFAAS). In the experimental setup, an oxygen flow was used to assist the sample combustion and also to transport the products towards the heated FF positioned above an air-acetylene flame. The hyphenated MIC-FF-AAS was applied for $\mathrm{Cd}$ and $\mathrm{Pb}$ determination in botanical samples. ${ }^{13}$ Another relevant topic being investigated is digestion methods using diluted nitric acid solution in closed vessels with microwave-assisted heating. The efficiency of this procedure and the reaction mechanism involved with were discussed in two recent papers with emphasis in the observed effects for coffee samples ${ }^{14}$ and the identification of reaction products by proton nuclear magnetic resonance ( ${ }^{1} \mathrm{HNMR}$ ) and ion pair reversed-phase liquid chromatography..$^{15}$ It was demonstrated that the process is critically dependent on the temperature gradient inside the closed vessel in the beginning of the digestion process $^{14}$ and the main residual carbon compounds are nitrobenzoic acid isomers when digesting animal and vegetal tissues. ${ }^{15}$

Microwave radiation was also applied for rapid extraction of fiber in animal feedstuffs using filter bags to contain the samples. ${ }^{16}$ The procedure was optimized using a factorial design and recoveries from 93 to $110 \%$ were obtained. The main advantages of the proposed procedure were the 7 -fold increment in sample throughput (i.e. from 40 to 280 per day) and reduction of both energy and reagents consumption. ${ }^{16}$

Chemometric strategies, such as Doehlert design, simplex, and principal component analysis, were applied for optimizing block digestion of beans ${ }^{17}$ and oyster tissue. ${ }^{18}$ It was experimentally demonstrated that the temperature is the most important parameter to promote efficient oxidation of organic compounds. ${ }^{17}$

Sample preparation based on the application of ultraviolet radiation was also investigated for voltammetric determination of $\mathrm{Al}(\mathrm{III}), \mathrm{Cd}(\mathrm{II}), \mathrm{Cu}(\mathrm{II}), \mathrm{Fe}(\mathrm{III}), \mathrm{Pb}$ (II), and $\mathrm{Zn}(\mathrm{II})$ in water and biological fluids. The authors demonstrated that using a high power ultraviolet radiation source $(400 \mathrm{~W})$ it was possible to liberate metals bound to the organic matrix for the determination of the total contents of elements in the samples. ${ }^{19}$

Preliminary steps before sample digestion are also important. Santos et al..$^{20}$ investigated the effects of grinding and sieving of bivalves, coffee and cowpea beans 
before multi-element analysis. It was demonstrated that both cryogenic grinder and ball mill were effective for promoting rapid sample homogenization and generating small particle sizes. However, contamination may be critical for some elements.

Other sample preparation strategy being intensely investigated is cloud point extraction, CPE. An innovative two-step sequential CPE was developed for determination of $\mathrm{Cd}, \mathrm{Cu}, \mathrm{Co}, \mathrm{Ni}$ and $\mathrm{Pb}$ in human serum, animal blood and food diet. ${ }^{21}$ The first CPE procedure was performed using o,o-diethyldithiophosphate for extracting $\mathrm{Cd}, \mathrm{Cu}$ and $\mathrm{Pb}$. The second $\mathrm{CPE}$ was made using 4-(2-pyridylazo) resorcinol for extracting Co and Ni. In both cases Triton ${ }^{\circledR}$ $\mathrm{X}-114$ was employed as non-ionic surfactant and all analytes were determined by inductively coupled plasma mass spectrometry (ICP-MS). A more conventional CPE procedure was applied for the determination of $\mathrm{Cd}$ and $\mathrm{Pb}$ in tobacco samples using thermospray flame furnace atomic absorption spectrometry, TS-FF-AAS. ${ }^{22}$ A nickel tube atomizer was used for improving the efficiency of atom cloud formation after sample introduction by thermospray employing a capillary ceramic tube. The efficiency of nickel and titanium tubes was compared for determination of $\mathrm{Cu}$ in biological samples and foods..$^{23}$ It was demonstrated that the insertion of a titanium tube inside a nickel tube improved the sensitivity by a factor of 4 and this effect was explained considering the formation of $\mathrm{TiO}_{2}$ inside the $\mathrm{Ti}$ tube, additionally this strategy increased the titanium tube lifetime.

In another work, a tungsten coil atomic absorption spectrometer was employed for $\mathrm{Cd}$ determination in urine after applying a CPE procedure for sample pretreatment. ${ }^{24}$ This is a challenging analytical task because Cd levels in urine are typically below $1 \mathrm{ng} \mathrm{mL}^{-1}$. Cloud point extraction reduced matrix interferences and an enrichment factor of 15. The partial removal of the matrix was operative for background correction based either on the measurement of absorption at a nearby wavelength or by temporal separation of background and atomic signals.

A novel approach in atomic absorption spectrometry was also proposed for mercury determination in biological samples. ${ }^{25}$ According to the proposed procedure mercury vapor can be generated at $\mathrm{pH} 13$ in a medium containing sodium hydroxide or other base without any further addition of another reducing agent, such as sodium borohydride and stannous chloride. The simple and innovative procedure seems also applicable for speciation because only $\mathrm{Hg}^{2+}$ in solution generated a signal and organomercury species were not detected.

Mercury speciation in tropical dolphins was also studied using classical procedures for extraction and measurement. Inorganic mercury, methylmercury, total organic mercury, and insoluble mercury, supposedly to be mercury selenide, were determined in the livers of dolphins from the Brazilian coast. ${ }^{26}$

The previously described studies demonstrated the use of modern sample preparation strategies and instrumental techniques for determination of trace concentrations of inorganic constituents. Despite all the evolution of atomic absorption spectrometry for simultaneous determination of elements, ${ }^{27,28}$ it can be observed a trend towards the use of ICP-MS. This is an important step forward and Brazil still must create a critical mass of research groups in this area.

In this sense, Barbosa Jr. and co-workers have published interesting papers related to the applications of ICP-MS to biological samples. For instance, a dynamic reaction cell ICP-MS, so called DRC-ICP-MS, was applied for determination of trace elements in blood using a simple dilute-and-shoot procedure. A $100 \mu \mathrm{L}$ volume of blood was diluted $1: 50 \mathrm{v} / \mathrm{v}$ using a solution containing $0.01 \% \mathrm{v} / \mathrm{v}$ Triton ${ }^{\circledast} \mathrm{X}-100$ and $0.5 \% \mathrm{v} / \mathrm{v}$ nitric acid. A DRC operated with ammonia as reaction gas was necessary for correcting isobaric interferences for $\mathrm{Cr}, \mathrm{Cu}, \mathrm{V}$ and $\mathrm{Zn} .{ }^{29} \mathrm{In}$ another work it was proposed the determination of trace elements in biological tissues by simple dissolution of the samples in $50 \% \mathrm{v} / \mathrm{v}$ tetramethylammonium hydroxide at room temperature. Complete dissolution was achieved in $12 \mathrm{~h}$ and the resulting solutions were diluted in the above mentioned diluent. ${ }^{30}$ Recently, this same group has directed efforts to establish reference values for trace elements in urine for the Brazilian population using a dilution procedure before ICPMS determinations. ${ }^{31}$ The relevance of this study is in the lack of reference data for biological fluids of the Brazilian population and the use of ICP-MS for performing these measurements is highly recommended. The study dealt with 412 ordinary urine samples from Brazilian healthy and non-exposed subjects to establish reference values.

Advancements are also observed for determination of organic compounds in biological samples. The area of chromatography is well-established in Brazil and there are consolidated groups in different regions. The cited papers are only selected examples of relevant applications.

Belaz et al. ${ }^{32}$ have developed a multidimensional achiral-chiral high performance liquid chromatography (HPLC) for determination of albendazole metabolites by direct injection of bovine plasma. Albendazole is a broad-spectrum anthelmintic agent and is widely used for treatment of veterinary and human helminthiasis. The developed procedure is appropriate for further pharmacokinetics and metabolism studies. In another interesting and well-developed study, a two-step liquid phase microextraction (LPME) and HPLC procedures were 
combined for the simultaneous analysis of the enantiomers of mefloquine and its main metabolite carboxymefloquine in plasma. ${ }^{33}$ The procedure was applied for plasmas of rats after oral administration of the racemic drugs to the animals.

Molecularly-imprinted polymers (MIP) are also being developed for organic analysis. Figueiredo et al. ${ }^{34}$ have developed an on-line molecularly-imprinted solid-phase extraction (MISPE) method for spectrophotometric determination of nicotine in urine samples of smokers. Nicotine promotes the reduction of $\mathrm{Mn}(\mathrm{VII})$ to $\mathrm{Mn}(\mathrm{VI})$ in an alkaline medium and this is the basis of the spectrophotometric method. Santos et al..$^{35}$ have prepared a MIP for selective catalytic determination of serotonin. The procedure is based on the synthesis of polymers with hemin introduced as the catalytic center to mimic the active site of peroxidase. No interference was observed by structurally similar compounds and the procedure was applied for the determination of serotonin in spiked blood serum samples.

An extraction procedure based on stir bar sorption followed by liquid chromatography was developed for determination of antidepressants in plasma samples from elderly depressed patients. ${ }^{36}$

Electroanalysis has also been applied for organic compounds determination, as demonstrated by the continuous monitoring of ascorbate transport through neuroblastoma cells with a ruthenium oxide hexacyanoferrate modified microelectrode. It was also demonstrated that the ascorbate uptake by control human neuroblastoma SHSY5Y cells and also in others cells was in agreement with the level of oxidative stress in these cells. ${ }^{37}$

The state of the art of electrochemistry and electroanalytical chemistry in Brazil was demonstrated by a recent issue of the Journal of the Brazilian Chemical Society dedicated to the XVI Brazilian Symposium of Electrochemistry and Electroanalytical Chemistry as discussed by Kubota and Torresi in the editorial section. ${ }^{38}$ This is one of the most traditional symposia in Brazil and this last edition reached 478 attendees coming from 56 different institutions.

\section{Foods}

Brazil is a major world player in agriculture dedicated to food and energy production. The plantations of sugarcane for sugar and ethanol large scale production are a worldwide recognized success in sustainability. ${ }^{39}$

The agriculture and food areas are critically dependent on analytical sciences for plant and soil analysis, and also for food safety. The international commerce is increasingly regulated and legislation is based on both the presence of essential nutrients and undesirable contaminants.
There are typical tropical products, such as Brazil nuts, babassu nuts and sapucaia, which require the development of tailored procedures for determining chemical forms of a specific element, such as barium in Brazil nuts, ${ }^{40}$ and arsenic, cadmium and lead in diverse products. ${ }^{41}$

Demands imposed by legislation may be exemplified by the determination of folic acid and minerals in corn and wheat flours. ${ }^{42-44}$ There is a specific legislation in Brazil enforcing the addition of folic acid and iron to corn and wheat flours. It is known that folic acid is one of the most important vitamins for normal human metabolic function. ${ }^{42}$ It was pointed out based on analysis of 70 samples that the Brazilian population seems to be exposed to inadequate concentrations of folic acid and iron when consuming enriched corn and wheat flours. Other inorganic constituents, such as $\mathrm{Ca}, \mathrm{Mg}, \mathrm{K}, \mathrm{P}, \mathrm{Cu}, \mathrm{Fe}, \mathrm{Mn}$ and $\mathrm{Zn}$, eventually present in wheat flours were determined by ICP OES in 54 samples collected in 15 Brazilian cities. ${ }^{43}$ Folic acid was also determined in wheat flour using liquid chromatography-andem mass spectrometry. ${ }^{44}$ Araujo et al. ${ }^{45}$ also worked with wheat flour analysis, but in this case solid and slurry sampling were employed for the determination of cadmium by electrothermal atomic absorption spectrometry (ETAAS). Both procedures led to agreeable results; however solid sampling was the method of choice due to faster analysis and better figures of merit. Direct solid analysis was also associated with high-resolution continuum source electrothermal atomic absorption spectrometry for determination of $\mathrm{Cd}$ and $\mathrm{Fe}$ in grain products. ${ }^{46}$ Again, it was concluded that most of the products did not contain the required minimum amount of iron. Finally, an interesting study was devoted to the calibration of direct solid analysis graphite furnace atomic absorption spectrometry (DSA-GFAAS) using spiked filter papers with $\mathrm{Cu}$ and $\mathrm{Zn}$ cryogenically ground as synthetic calibrating standards. ${ }^{47}$ The feasibility of this strategy was convincingly proved.

Soybeans are one of the main exported food products by Brazil. The quality of the product is reduced when leaves are affected by soybean rust, a disease caused by a fungus that causes severe farming losses. Mendes et al. ${ }^{48}$ have developed an electrochemical immunosensor based on impedance measurements to detect Asian rust on soybeans leaf extract at the early stages of the disease. César et al. ${ }^{49}$ also worked with soybeans focusing the determination of genistein and genistin in soy dry extracts after reaction with aluminum chloride and measurement by spectrophotometry. Genistein is one of the major isoflavones found in soy extracts and soy isoflavones are the most frequently used phytoestrogens. Martin et al..$^{50}$ also evaluated the nutritional benefits of soy ingestion by 
determining fatty acids with emphasis on trans isomers. The effects of thermal treatment applied to soybean oil during the deodorization step were investigated.

Brazil is the major world producer of coffee, which is the most popular beverage in the world and its value as a commodity depends on the variety and processing. An electrospray ionization mass spectrometry fingerprinting was developed for green and roasted coffees for differentiating them by different stages of ripeness (green, ripe, and overripe), post-harvesting process (dry, wet, and semi-wet) and cup quality. ${ }^{51}$ The quality of coffee was also investigated by the determination of fatty acid profile ${ }^{52}$ and by evaluating the prediction of sensory properties by solid phase microextraction-gas chromatography and partial least squares. ${ }^{53}$ In the first work it was shown that the fatty acid methyl ester composition could not be used to detect corn adulteration in commercial coffees. ${ }^{52}$

In a completely diverse application but also related to food control, Medeiros et al. ${ }^{54}$ developed a voltammetric procedure for the determination of sodium cyclamate in dietary products using a boron-doped diamond electrode.

Milk is an important source of nutrients and vitamins for infants. Soares et al. ${ }^{55}$ have determined retinol concentration in seven ultra-high temperature milks and have found that only one product had a concentration below the normal requirement for humans. On the other hand, residues of veterinary products and pesticides are a critical issue for milk. Different strategies have been applied for determination of these undesirable constituents, such as gas chromatography (GC) with electron capture detection for the determination of pyrethroids, ${ }^{56}$ HPLC with fluorescence detection for the simultaneous determination of abamectin and ivermectin, ${ }^{57}$ and HPLC with amperometric detection using a boron-doped diamond electrode for the simultaneous determination of sulfomethoxazole and trimethoprim. ${ }^{58}$ All these procedures are important for applying regulative legislation and public health. Another significant application is the control of the composition of juices. In this sense, Scherer et al. ${ }^{59}$ have applied HPLC with ultraviolet detection for the determination of tartaric, malic, ascorbic, and citric acids in tropical juices. It was shown that acerola pulp presented the highest ascorbic acid concentration and that occur a small decrease of organic acids contents during storage. Malic and citric acids seem to be more stable than tartaric and ascorbic acids. In other studies, inorganic constituents were determined for evaluating potential nutritional and toxicological effects. Boa Morte et al. ${ }^{60}$ have developed a sequential injection fluorimetric procedure for the determination of tin in canned fruit juices. Trace elements and sodium were determined in grape juice and it was found that the concentrations of all tested contaminants, i.e. As, $\mathrm{Cd}, \mathrm{Cr}$, $\mathrm{Cu}, \mathrm{Ni}, \mathrm{Pb}, \mathrm{Sb}$, and $\mathrm{Zn}$, complied with maximum tolerable levels according to the Brazilian legislation. ${ }^{61}$ Copper was also determined in tropical juices using two different strategies in atomic absorption spectrometry. ${ }^{62,63}$ The first one was based on fast sequential flame atomic absorption spectrometry (FS-FAAS) and the accuracy was improved using indium as internal standard. ${ }^{62}$ The second one employed thermospray flame furnace atomic absorption spectrometry (TS-FF-AAS) for direct determination of copper, cadmium and lead in grape juices and wines. ${ }^{63}$ Despite not requiring previous digestion of the samples, calibration must be performed using the standard additions method for correcting matrix interferences. ETAAS was also applied for the determination of cadmium ${ }^{64}$ and lead ${ }^{65}$ in wines. Iron and manganese were also determined in wines using FS-FAAS and adding cobalt and indium as internal standards, respectively. ${ }^{66}$

Tea is also a major staple and the determination of its chemical composition and additives are important. Two recent papers have investigated the development of sensors for the determination of catechin ${ }^{67}$ and saccharin ${ }^{68}$ in teas. The former proposed a catechol oxidase biomimetic sensor based on a novel $\mathrm{Cu}$ (II) complex for the determination of catechin in green tea. ${ }^{67}$ The biomimetic sensor was stable for 800 determinations. The latter proposed an easily constructed potentiometric sensor using mercurous saccharinate on a $\mathrm{Pt}, \mathrm{Hg}$ electrode. The electrode was characterized by fast response time (10-30 s) and long lifetime (10 months). ${ }^{68}$ In other approach, a multicommuted flow system was employed for determination of tannin in tea and wine samples, exploiting $\mathrm{Cu}(\mathrm{II})$ reduction and complex formation with 4,4'-dicarboxy-2,2'-biquinoline. ${ }^{69}$

Another popular beverage in Brazil and world-wide consumed is obtained from fermentation and distillation of sugar-cane, popularly called as cachaça. One of the focuses is the determination of polycyclic aromatic hydrocarbons, PHAs, because of their potential effects on human health. Thus, HPLC with fluorescence detection was employed for Galinaro and Franco ${ }^{70}$ and Caruso and Alaburda. ${ }^{71}$ The first work had a more general character and studied the determination of 15 PHAs in 57 samples of distillates (cachaça, rum, whiskey, and even alcohol fuel). ${ }^{70}$ On the other hand, the second study was centered in the evaluation of three extraction procedures, i.e. one using solid phase extraction (SPE) for extraction and clean-up and two others based on liquid-liquid extraction followed by silica gel chromatography clean-up, for the determination of benzo(A)pyrene, $\mathrm{BaP}$, in cachaças. $\mathrm{BaP}$ is the most studied polycyclic aromatic hidrocarbon (PAH) 
and it could be used as a marker for the occurrence and evaluation of carcinogenic potential of PAH in beverages and foods. ${ }^{71}$ The three extraction procedures tested were efficient, although SPE was the cheapest, fastest and least solvent-consuming. Twenty samples of cachaça were tested and concentrations ranged from below the limit of detection $\left(0.03 \mu \mathrm{g} \mathrm{L} \mathrm{L}^{-1}\right)$ to $0.49 \mu \mathrm{g} \mathrm{\textrm {L } ^ { - 1 }}$.

Another critical constituent with carcinogenic potential that may be present in cachaça is ethyl carbamate. Studies have investigated the chemical factors that can lead to its production during storage, but no correlation was found with copper content, ${ }^{72,73} \mathrm{pH}$ and alcohol content ${ }^{73}$ of the samples. All determinations were performed using gas chromatography-mass spectrometry (GC-MS).

Fingerprinting pattern recognition based on twodimensional GC and GC associated with time-of-flight mass spectrometry was applied for cachaça samples during the fermentation process and after ageing in different wood materials. ${ }^{74}$ It was demonstrated for quality control purposes that a simple observation of the contour plots allows the identification of the type of wood used in the ageing process. Additionally, it was shown that along progression of the distillation process, 70 compounds appear to visually discriminate between samples. Finally, control of other possible constituents such as formaldehyde and acetaldehyde, and arsenic, copper and lead in cachaças was performed by using HPLC $^{75}$ and GFAAS ${ }^{76}$ respectively.

Research papers dealing with beer were less common. Lowinsohn and Bertotti have developed an amperometric lactate biosensor with lactate oxidase immobilized into a Prussian Blue modified electrode and applied this biosensor in an amperometric flow injection procedure for the determination of lactate in beer. ${ }^{77}$ In another study the efficiency of different silica-based materials was evaluated for extraction of volatiles of beer. ${ }^{78}$ It was shown that the modification of silica with alkyl groups affected the preconcentrated amount of the target molecules in the headspace, and this effect was more pronounced than the addition of sodium chloride or the use of ultrasound.

Analytical procedures for characterization of Brazilian honeys were also investigated. Selected studies have aimed to establish the physico-chemical characteristics of honeys obtained in Brazil northeast, ${ }^{79}$ the antioxidant action of the bee pollen produced in the southern region of Brazil,${ }^{80}$ and the concentration of hydrogen peroxide in honeys as a product of biological reactions catalyzed by several oxidase enzymes. ${ }^{81}$ This latter aspect is relevant for the characterization and selection of honey samples for its use as an antimicrobial agent. The determination of the hydrogen peroxide was performed using differential amperometry associated with flow injection analysis.
Another fundamental research area is the determination of drugs and pesticides in foods. Recently Jardim et al. ${ }^{82}$ have emphasized that the residues of pesticides in foods is a global environmental problem and there is an increasingly demand for the validation of analytical methods of multiresidue pesticide determination in these samples. Most research works found in literature have applied chromatography frequently associated with mass spectrometry. These works investigated different types of residues and products, such as sulfonamides ${ }^{83}$ and streptomycin ${ }^{84}$ in honey, buprofezin, tetradifon, vinclozolin, and bifenthrin in propolis ${ }^{85}$ glyphosate in soybeans, ${ }^{86}$ chlorpyriphos, $\lambda$-cyhalithrin, cypermethrin, and deltamethrin in tomatoes, ${ }^{87}$ chlorothalonil in tomatoes and cucumbers, ${ }^{88}$ fenitrothion in tomatoes, ${ }^{89}$ dimethoate, malathion, lufenuron, trichlorfon, carbofuran, 3-hydroxycarbofuran, difenoconazole, and thiabendazole in coconut pulp, ${ }^{90}$ chlorpyriphos, cypermethrin, and fipronil in bovine plasma. ${ }^{91} \mathrm{~A}$ non-chromatographic procedure was also developed for the determination of toxic arsenic species in vegetables using hydride generation-atomic fluorescence spectrometry. ${ }^{92}$

This strong research activity in analytical chemistry applied to food analysis demonstrated that research laboratories and human resources in Brazil are capable of delivering trustable analytical results for supporting internal consumption and exportation of agricultural and food products according to national and abroad legislations.

\section{Environmental}

The climate changes in the world are a public concern in several countries and international organizations. In Brazil many research groups are dedicated to the analysis of air, sediments, soils, and agronomical among other environmental samples..$^{93}$ The most frequently studied sample is water, mainly due to its ability to disseminate diseases and several aspects of contaminants are reported at the water/air and soil/air interfaces. ${ }^{94}$ Kehrig et al. ${ }^{95}$ determined methylmercury $(\mathrm{MeHg}$ ) and total $\mathrm{Hg}$ in water and fish samples from two reservoirs within Brazilian Amazon and observed that the bioconcentration factor (BCF) is higher in ecosystem rich in dissolved organic matter. Santos et al. ${ }^{96}$ coupled HPLC and ICP-MS for determination of organic and inorganic $\mathrm{Hg}$ species in water samples. The authors used sodium diethyldithiocarbamate immobilized in polyurethane foam to preconcentrate $\mathrm{Hg}(\mathrm{II})$ and $\mathrm{MeHg}(\mathrm{I})$. Oliveira et al. ${ }^{97}$ determined $\mathrm{Cr}$ in waters derived from petroleum exploration employing ETAAS combining Pd and HF as chemical modifiers. Carbo et al. ${ }^{98}$ determined pesticides multiresidues in 
groundwater using HPLC with diode array detection and the samples were collected in cotton growing areas.

Organophosphate and pyrethroid pesticides were determined in water samples by Pinheiro and De Andrade..$^{99}$ The authors used single-drop microextracton (SDME) and the pesticides were determined using GC with flame ionization detector (GC-FID). Sabin et al. ${ }^{100}$ proposed a multiresidue determination of pesticides in drinking water using GC-mass spectrometry after solid-phase extraction. The proposed method was developed and validated for determination of 20 pesticides regulated by the Brazilian legislation for drinking water. Rodrigues et al. ${ }^{101}$ proposed a green and sensitive method to determine phenols in water and wastewater samples using a liquid-liquid extraction technique. Santos and Masini ${ }^{102}$ determined methyl parathion in water samples using square wave adsorptive cathodic stripping voltammetry. Voltammetric techniques are suitable for redox speciation and Nascimento et al. ${ }^{103}$ proposed a method for Se(IV) and $\mathrm{Se}(\mathrm{VI})$ determination in saline samples like seawater, hydrothermal and hemodialysis fluids. Borba et al. ${ }^{104}$ determined total and As species in groundwater based on the different rates of arsine formation. Duarte et al. ${ }^{105}$ developed a sensitive amperometric sensor for oxygen in pond and tap water with relative standard deviation of $2.0 \%$. Another amperometric sensor was developed by Souza et al. ${ }^{106}$ for nitrite determination in water samples. Santos et al. ${ }^{107}$ presented a systematic comparison among spectrophotometric flow injection procedures for sulfide determination based on phenothiazine dye production from diverse aromatic $p$-substituted amines. Melchert and Rocha ${ }^{108}$ presented a flow-based procedure for turbidimetric sulfate determination in waters. The mixing conditions were improved with the help of solenoid micro-pumps and sensitivity was increased by coupling a long-pathlength flow cell based on a liquid core waveguide.

Fortes et al. ${ }^{109}$ proposed an expert flow system for sequential turbidimetric determination of chloride and sulfate in natural waters. The system was computer-controlled and presented enhanced figures of merit when compared with reference methods. Infante et al. ${ }^{110}$ proposed a green flow-based procedure for fluorimetric determination of acid-dissociable cyanide in natural waters exploiting multicommutation. The determination was based on the reaction among cyanide, $o$-phthalaldehyde and glycine yielding a highly fluorescent isoindole derivative. The herbicide paraquat was also determined in natural waters using a multicommuted flow system with solenoid micropumps. ${ }^{111}$ Eberlin and Silva ${ }^{112}$ proposed a method combining solid phase microextraction (SPME) and direct mass spectrometric analysis for chlorophenols determination in water. Carletto et al. ${ }^{113}$ used a hollow fiber for Cd(II) preconcentration in water samples and the enrichment factor was 120 . Menegário et al. ${ }^{114}$ performed an on-line redox speciation analysis of Sb using L-proline immobilized on controlled pore glass and hydride generation ICP OES. The authors observed that $\mathrm{Sb}(\mathrm{V})$ was not retained by the column and the retained $\mathrm{Sb}$ (III) was determined after elution. Matos et al. ${ }^{115}$ used a cloud point extraction procedure for determination of the chromium species in natural water samples. A hydrophobic Cr(III) complex was formed with 1-(2-pyridilazo)-2-naphtol (PAN) and separated using Triton ${ }^{\circledR} \mathrm{X}-114$. Goveia et al. ${ }^{116}$ proposed a cellulose bag and an ion exchanger to understand environmental phenomena related to the complexation, transport, stability, and lability of metal species in aquatic systems rich in organic matter. The cellulose base was organomodified with $p$-aminobenzoic acid groups. Pimentel et al. ${ }^{117}$ determined 10 elements in water samples from an oil field in Rio Grande do Norte (Brazil) using synchrotron radiation total reflection X-ray fluorescence (SR-TXRF). Brum et al. ${ }^{118}$ used Doehlert design to optimize a liquid-liquid extraction of PAH's (polycyclic aromatic hydrocarbons) from natural contaminated waters prior to determination by liquid chromatography with fluorescence detection. Fernandes et al. ${ }^{119}$ used a light emitting diode (LED) spectrometer for mechanized multipumping determination of Se in natural waters. The method was based on the reaction of the analyte with $\mathrm{KI}$ in acid medium to liberate iodine, which oxidizes variamine blue forming a violet-color species which absorb at $530 \mathrm{~nm}$.

Some research groups studied alternative materials to retain metal ions. Gonzáles et al. ${ }^{120}$ for example, used peat as natural solid-phase for $\mathrm{Cu}$ preconcentration. This approach was used for in-line $\mathrm{Cu}$ concentration prior to FAAS determination. Multi-walled carbon nanotube has been used for electrodes preparation and Moraes et al. ${ }^{121}$ proposed a method for direct determination of carbaryl using multi-walled carbon nanotube/cobalt phthalocyanine.

São Paulo city is nowadays one of the biggest cities of the world and its rainwater quality for samples collected in 2003 was evaluated by Fontenele et al. ${ }^{122}$ by determining $\mathrm{Cd}, \mathrm{Pb}, \mathrm{Cu}$ and some anions concentrations. They observed that the predominant species were $\mathrm{NO}_{3}$, $\mathrm{SO}_{4}{ }^{2-}$ and $\mathrm{Ca}^{2+}$. Pacioni et al. ${ }^{123}$ avoided degradation or derivatization reaction adding macrocyclic host such as $p$-sulfonatocalix(6)arene (C6S) on the fluorescence of benzoimidazolic fungicides (benomyl and carbendazim). The interaction between the fungicides and $\mathrm{C} 6 \mathrm{~S}$ was strong and attributed to electrostatic forces.

Maltez et al. ${ }^{124}$ used single drop micro-extraction with $o, o$-diethyl dithiophosphate for the determination of $\mathrm{Pb}$ by ETAAS. The authors observed a low sensitivity probably 
due to infiltration of the organic drop into the pyrolytic graphite platform and $\mathrm{W}$ was thermally deposited onto the surface to overcome this problem.

Sediment analysis is an important field in the environment because this compartment can carry information about contaminations in the aquatic body. ${ }^{125}$ Several research groups have investigated this sample in Brazil and $\mathrm{Hg}$ is one of the most frequently determined analyte. Guanabara Bay in Rio de Janeiro State (Brazil) was studied in relation to the accumulation of $\mathrm{Hg}$ in sediment cores and concentrations up to $7500 \mathrm{ng} \mathrm{g}^{-1}$ were observed. ${ }^{126}$ Others investigated areas were Santos and Cubatão (São Paulo State) due to the high industrial activity. Luiz-Silva et al. ${ }^{127}$ determined 38 elements in sediments from the Santos-Cubatão estuarine system using ICP-MS and they observed that $\mathrm{Cr}, \mathrm{Mn}, \mathrm{Ni}, \mathrm{Zn}, \mathrm{Ga}, \mathrm{Ag}, \mathrm{Cd}$, $\mathrm{Sn}, \mathrm{Sb}, \mathrm{Pb}$ and $\mathrm{Bi}$ were associated with steel plant-derived $\mathrm{Fe}$ concentrations. In another study Hortellani et al. ${ }^{128}$ evaluated 6 elements in 41 sediment samples from Santos-São Vicente estuarine system. $\mathrm{Zn}, \mathrm{Ni}, \mathrm{Pb}, \mathrm{Cd}, \mathrm{Cr}$ and $\mathrm{Hg}$ concentrations were high and seemed to be associated with human activities. Silva et al. ${ }^{129}$ determined organochlorine pesticides in Piracicaba river basin (São Paulo State) in sediment, bivalve and fish samples. They observed that the isomer $\alpha$ and $\gamma$ of $\mathrm{HCH}$ (hexachlorocyclohexane) and heptachlor were most frequently detected in samples of sediments and specimens of bivalve and fish. Garcia et al. ${ }^{130}$ evaluated regional geochemical baselines and controlling factors for trace metals in sediments from the Poxim River (Sergipe State, Brazil). The authors did not observe a correlation among organic matter and the metals determined. Cavalcante et al. ${ }^{131}$ compared extraction techniques and clean-up procedures for PAH's analysis in sediments of the Ceará State (Brazil) coast and they observed that the highest recoveries were obtained with soxhlet and ultrasonic techniques. Hatje et al. ${ }^{132}$ investigated trace elements extractions with hydrochloric acid using factorial design. The authors concluded that the ultrasound-assisted leaching could reduce the conventional extraction time from $12 \mathrm{~h}$ to $50 \mathrm{~min}$ or even less (for $\mathrm{Pb}$, for example). Lopes et al. ${ }^{133}$ applied multivariate techniques in the optimization of a procedure for the determination of bioavailable concentration of Selenium and As in estuarine sediments by ICP OES. Se and As were determined employing a hydride generator and the interferences were minimized using high $\mathrm{HCl}$ concentration. Felizzola et al. ${ }^{134}$ determined butyltin in sediments from Todos os Santos bay (Bahia State, Brazil) using gas chromatography with pulsed flame photometric detection.

Another parameter to be considered is the quantity of the element that is really available for biological system interaction. ${ }^{135}$ In this way, selective extraction procedures are useful to identify if a given element is presented in an inert or bioavailable form. ${ }^{136}$ Bevilacqua et al. ${ }^{137}$ applied a selective extraction procedure for toxic metals determination in bottom sediments from Tietê river (São Paulo State) and they observed high concentrations of heavy metals at Pirapora reservoir, which is closer to the metropolitan area of São Paulo. Matos and Arruda ${ }^{138}$ proposed a derivatization strategy for Co determination using TS-FF-AAS. As this technique is suitable for volatile elements, the authors presented a procedure to generate volatile $\mathrm{Co}$, producing a complex between this element and sodium diethyldithiocarbamate (DDTC). Mangrich et al. ${ }^{139}$ combined several techniques, such as electron paramagnetic resonance (EPR), near-infrared spectroscopy and chemical elemental analyses, for pollution level monitoring in mangrove sediments. Using EPR it was possible to nondestructively assess the environmental pollution level of coastline. Araujo et al. ${ }^{140}$ determined $\mathrm{Sb}$ in sediment reference materials using direct solid sampling using high-resolution continuum source ETAAS and Ir as permanent modifier.

Biological samples can be used as biomarkers for trace elements exposure and Torres et al. ${ }^{141}$ determined an organochlorine insecticide (DDT) in human breast milk. Even after 12 years that DDT was considered forbidden for vector controls programs its concentration was relatively elevated in the studied samples. Batista et al. ${ }^{142}$ determined $\mathrm{Cd}, \mathrm{Cu}, \mathrm{Mn}, \mathrm{Ni}, \mathrm{Pb}$ and $\mathrm{Zn}$ in nail by ICP-MS. The samples were solubilized using tetramethylammonium hydroxide avoiding acid digestion prior to determinations. Seixas et al. ${ }^{143}$ determined trace elements in different species of cetacean from Rio de Janeiro (Brazil) coast and no gender differences were observed on the bioaccumulation of trace elements. Plant extracts were analyzed by Franzoi et al. ${ }^{144}$ for rosmarinic determination. In the experimental procedure the authors used ionic liquids (ILs) and laccase to produce a biosensor. Melo et al. ${ }^{145}$ proposed a simple and sensitive method for detection of diquat herbicide in water and potato samples using dental amalgam electrode. Santos et al. ${ }^{146}$ proposed an imaging mass spectrometry method using laser ablation inductively coupled plasma spectrometry for $\mathrm{Cu}$, $\mathrm{Zn}, \mathrm{Cd}, \mathrm{Hg}$ and $\mathrm{Pb}$ determination and metal distribution in longitudinal tissue sections of marine snail Nassarius retic. Almeida et al. ${ }^{147}$ optimized a methodology to measure gaseous elemental $\mathrm{Hg}$ in Amazon atmosphere. Organic compounds like formaldehyde was the analyte target by Rocha et al.. ${ }^{148}$ Formaldehyde is the most toxic of the volatile carbonyl compounds present in outdoor air. Lima and Pereira Netto $^{149}$ evaluated total suspended particulate and associated PAH's in Niterói (Rio de Janeiro, Brazil). It was not possible to correlate the individual and total PAH's concentrations with temperature, relative humidity or wind 
speed and the main source of PAH's in the studied area was vehicular emission. In other works Marques et al. ${ }^{150}$ and Rocha et al. ${ }^{151}$ studied particle-associated PAH's in Rio de Janeiro and Salvador (Bahia State, Brazil), respectively. Loyola et al. ${ }^{152}$ collected total particulate matter samples in a bus station and determined $\mathrm{Ca}, \mathrm{Mg}, \mathrm{Fe}, \mathrm{Al}, \mathrm{Co}, \mathrm{Ni}, \mathrm{Cd}$, $\mathrm{Cr}$ and $\mathrm{Pb}$ using ICP OES concluding that the sources of $\mathrm{Zn}$ and $\mathrm{Cu}$ were probably fuel and oil composition.

The sugar cane production can be a source for herbicides contamination in soils and Lourencetti et al. ${ }^{153}$ proposed a method for three herbicides determination in soils cultivated with this crop. The authors combined SPE-HPLC-UV method for the simultaneous determination. Raposo Jr. et al. ${ }^{154}$ evaluated alternative lines of $\mathrm{Fe}$ for sequential multi-element determination of $\mathrm{Cu}, \mathrm{Fe}, \mathrm{Mn}$ and $\mathrm{Zn}$ in soil extracts by HR-CS FAAS. Matos et al. ${ }^{155}$ determined $\mathrm{Cr}(\mathrm{VI})$ and $\mathrm{Cr}(\mathrm{III})$ in soils accidentally contaminated with sulphochromic solution. Oliveira et al. ${ }^{156}$ investigated nonflooded and flooded soils through the calculation of stability and activation energies associated with the dehydration and thermal decomposition of humic substances using TGA (thermogravimetric analysis) and DTA (differential thermal analysis), $\mathrm{EPR}$ and $\mathrm{C} / \mathrm{H}, \mathrm{C} / \mathrm{N}$ and $\mathrm{C} / \mathrm{O}$ atomic ratios.

Several types of samples were also monitored by Brazilian research groups, such as workplace environments of cement industries processing organic residues. ${ }^{157}$ This type of workplace presents a potential risk for producing PAH's. Suchara et al. ${ }^{158}$ presented a method for quantification of pharmaceutical residues in sewage effluents and the analytical parameters were evaluated with statistical methods. Souza et al. ${ }^{159}$ developed an integrated flow injection system for the electro-oxidative leaching of uranium from geological samples followed by its spectrophotometric determination with arsenazo III. Pontes et al. ${ }^{160}$ also analyzed geological samples and proposed a simplified version of the total Kjeldahl nitrogen method using an ammonia extraction ultrasound-assisted purgeand-trap system and ion chromatography. Macedo et al. ${ }^{161}$ determined total As and As(III) in phosphate fertilizers and phosphate rocks using HG-AAS and the operational conditions were optimized using multivariate approach.

\section{Fuels}

Biofuels such as ethanol and biodiesel are alternatives to replace fossil fuels, with a number of economical and environmental advantages. Brazil is one of the major players in this field and the development of analytical procedures has followed this trend. The main aim has been simpler and faster methodologies for determination of quality control parameters and contaminants. Review articles describing analytical procedures for biodiesel characterization ${ }^{162}$ and evaluation of quality parameters ${ }^{163}$ were recently published.

Biodiesel is usually produced by a base-catalyzed transesterification reaction of a vegetal oil or animal fat and methanol or ethanol. Determination of the residual alcohol content and the concentration of glycerol, formed as subproduct, are thus important to evaluate the quality of the biofuel. A flow-based enzymatic procedure was proposed for determination of methanol after analyte separation in a PTFE membrane. ${ }^{164}$ Methanol in the acceptor stream yielded hydrogen peroxide in a reaction catalyzed by immobilized alcohol oxidase, being the reaction product quantified by spectrophotometry. The detection limit was estimated as $0.0002 \%(\mathrm{~m} / \mathrm{m})$ with a coefficient of variation lower than $5.0 \%$. The electrooxidation of the analyte on platinum electrodes was proposed for determination of free glycerol in biodiesel by the potential cycling technique. ${ }^{165}$ The analyte was determined after extraction with water and the procedure presented linear response within 15 and $150 \mathrm{mg} \mathrm{L}^{-1}$. In other approach, the raw materials used to produce biodiesel were identified by mass spectrometry with selective ion monitoring coupled to gas chromatography. ${ }^{166}$ This study indicates the predominance of biodiesel produced from soybean oil and methanol in the analyzed commercial mixtures diesel/biodiesel.

Fast and reliable analytical procedures to estimate the biodiesel content and detection of adulterations by addition of vegetal oils are required in view of the increased use of this alternative fuel. A procedure for evaluation of biodiesel quality was developed exploiting chemometrics and nuclear magnetic resonance spectroscopy ( ${ }^{1} \mathrm{H}$ NMR). ${ }^{167}$ Partial least squares regression (PLS) and principal components regression (PCR) algorithms were effective for quantification of both biodiesel and vegetable oil in mixtures with mineral diesel. Another work proposed the synchronous spectrofluorimetry and data processing by PLS, PCR or linear discriminant analysis to quantify the residual vegetal oil content in biodiesel or diesel/biodiesel blends. ${ }^{168}$ In other work, a procedure based on multivariate control charts using data obtained by NIR was proposed to evaluate the quality of commercial blends with diesel. ${ }^{169}$ The proposed model was suitable to identify unconformities in relation to biodiesel content, contamination of biodiesel with vegetal oil and of diesel with naphtha. Guarieiro et al. ${ }^{170}$ developed a procedure based on mid-infrared spectroscopy $\left(\mathrm{C}=\mathrm{O}\right.$ bands at 1750 and $\left.1735 \mathrm{~cm}^{-1}\right)$ to estimate the biodiesel content in commercial blends, with a detection limit of $0.1 \%$ and relative error lower than $10 \%$.

Several analytical procedures have focused the determination of metals in biofuels. Solid-phase 
in-line concentration in flow-based systems was applied for determination of $\mathrm{Cd}$ in $\mu \mathrm{g} \mathrm{L}^{-1}$ range in ethanol fuel by FAAS. The studies explored analyte retention in biosorbents such as Moringa oleifera ${ }^{171}$ or vermicompost used as garden fertilizer. ${ }^{172}$ Cadmium and $\mathrm{Pb}$ were also determined in ethanol fuel by GFAAS, exploiting a filter furnace to avoid using chemical modifiers, stabilize the volatile analytes and to short the pyrolysis step. ${ }^{173}$ Detection limits were $0.1 \mu \mathrm{g} \mathrm{L}^{-1} \mathrm{Cd}$ and $0.3 \mu \mathrm{g} \mathrm{L}-1 \mathrm{~Pb}$, with recoveries in the 90 to $120 \%$ range.

Formation of microemulsions has been exploited as an alternative for sample nebulization in atomic spectrometric techniques, such as FAAS, FAES and ICP OES. A microemulsion formed from $n$-pentanol, water and biodiesel in the presence of Triton ${ }^{\circledR}$ X-100 was proposed for determination of $\mathrm{Na}$ and $\mathrm{K}$ in biodiesel by FAAS. ${ }^{174}$ Results for biodiesel from different fat sources agreed with those obtained by the procedures recommended by the European norms EN14108 and EN14109 based on sample dilution in organic solvents, but samples and reference solutions prepared by the proposed procedure were more stable (3 days against $1 \mathrm{~h}$ for the official procedure). Other advantages include a 2-fold lower detection limit and better precision (lower than 1.0\%). Flame AES with sample introduction as a microemulsion formed from sample, $n$-propanol and a diluted acid solution was also applied for determination of $\mathrm{Na}$ and $\mathrm{K}$ in biodiesel, with a detection limit of $0.1 \mu \mathrm{g} \mathrm{g}^{-1} \cdot{ }^{175}$ Determination of $\mathrm{Ca}, \mathrm{Cu}$, $\mathrm{Fe}, \mathrm{Mg}, \mathrm{Mn}, \mathrm{Na}$ and $\mathrm{P}$ in biodiesel by ICP OES with axial and radial views was also feasible from samples emulsified with an aqueous Triton ${ }^{\circledR} \mathrm{X}-100$ solution and yttrium as internal standard. ${ }^{176}$ Calibration was carried out with aqueous solutions, avoiding the use of unstable mixtures with organic solvents, yielding recoveries in the 90 to $109 \%$ range. An ion-selective electrode modified with nickel hexacyanoferrate was also proposed for potentiometric potassium determination in the range $4.0 \times 10^{-5}$ to $1.0 \times 10^{-2} \mathrm{~mol} \mathrm{~L}^{-1}$ in biodiesel, after liquid-liquid extraction with $0.1 \mathrm{~mol} \mathrm{~L}^{-1} \mathrm{HCl}^{177}$

Different sample preparation strategies have been explored for element determination in complex samples such as lubricating oils, petroleum coke and coal. Sample pretreatments based on microwave-assisted acid decomposition, direct dilution in kerosene and formation of an oil-in-water emulsion with sonication were compared for determination of $\mathrm{Cu}, \mathrm{Cr}, \mathrm{Fe}, \mathrm{Ni}, \mathrm{Pb}, \mathrm{Sb}$ and $\mathrm{Zn}$ in lubricating oils by high resolution continuum source FAAS. ${ }^{178}$ The emulsion strategy yielded better results except for chromium, in view of sample contamination by the metal ion released from the ultrasound probe. Aiming to avoid the previous sample treatment, the solid sampling strategy was adopted for direct determination of $\mathrm{Cr}$ and $\mathrm{Ni}$ in lubricating oils by GFAAS with Zeeman-effect background correction. An in-situ digestion step with a mixture of $\mathrm{HNO}_{3}, \mathrm{H}_{2} \mathrm{O}_{2}$ and Triton ${ }^{\circledR} \mathrm{X}-100$ was used to minimize the organic content before atomization. ${ }^{179}$ The previously mentioned microwave-induced combustion technique in closed vessel ${ }^{12,13}$ was also applied for sulfur determination in petroleum coke ${ }^{180}$ and halogens in coal. ${ }^{181}$

Sulfate and chloride are undesirable species in ethanol fuel, which can intensify corrosion of metallic parts of engines and fuel pipes. An ingenious procedure was developed for indirect determination of these anions in ethanol, exploiting the precipitation reactions with $\mathrm{Ba}$ (II) and $\mathrm{Ag}(\mathrm{I})$. Measurements of the solids retained in a filter paper were carried out by energy dispersive $\mathrm{X}$-ray fluorescence, resulting in detection limits of $25 \mu \mathrm{g} \mathrm{L}^{-1} \mathrm{Cl}^{-}$ and $30 \mu \mathrm{g} \mathrm{L}^{-1} \mathrm{SO}_{4}{ }^{2-}$, with coefficients of variation better than $7 \%{ }^{182}$

Fast and green procedures were also developed for determining parameters of interest for quality control of gasoline. A procedure for determination of both ethanol and specific gravity was developed by means of processing data of distillation curves by multivariate analysis (PLS). ${ }^{183}$ For the successful determination of these parameters, the calibration model needs to include samples representative of the variety of composition of this fuel in the market. Near-infrared spectroscopy was exploited by Fernandes et al. ${ }^{184}$ for the simultaneous determination of methanol and ethanol in gasoline, with spectral data processing by PLS-2. Composition of gasoline and the spectral range were critical aspects, because toluene and $o$-xylene interfere in ethanol determination while isooctane and xylene isomers affected methanol determination.

\section{Pharmaceuticals}

A search in the literature reveals a large number of analytical procedures devoted to determination of pharmaceuticals and their metabolites. In spite of this, there is a clear demand for procedures for the determination of new drugs as well as non-destructive, inexpensive and fast alternatives for quality control of medicines used in large scale. This trend has been followed by Brazilian researchers, as indicated by relevant recent applications. On the other hand, new analytical approaches or characteristics of electrodes designed with new materials have been demonstrated by means of applications related to pharmaceuticals.

Chromatography is well-established for determination of drugs and metabolites, being usually recommended by Pharmacopeias. Recent applications and method validation 
carried out by Brazilian authors include determination of losartan, ${ }^{185}$ nadolol, ${ }^{186}$ sotalol hydrochloride ${ }^{187}$ and pancuronin bromide ${ }^{188}$ by HPLC. GC-MS was employed for the simultaneous determination of amphetamines and ephedrines in urine with an alternative chemical derivatization. ${ }^{189}$ In other work, the determination of toluene in urine aiming evaluation of occupational exposure to the solvent was carried out by GC with detection by flame ionization. ${ }^{190}$

The number of applications of capillary electrophoresis, including pharmaceutical analysis, has rapidly increased in view of fast separations and higher resolution, also avoiding the use of toxic solvents. A capillary zone electrophoresis (CZE) procedure was developed and validated for determination of 7 antimicrobials exploiting experimental design and calculations of effective mobility. ${ }^{191}$ Results agreed with those attained by the HPLC procedure recommended by the United States Pharmacopoeia. Validation of a CZE procedure for the determination of fluoroquinolones was also carried out. ${ }^{192}$

Several strategies have been exploited for simultaneous determination of drugs by electroanalytical procedures. For the determination of ascorbic acid, dopamine and uric acid, a pyrolytic graphite electrode was modified with a melanin polymeric film produced by anodization in dopamine medium. In view of the modified surface, peak separation better than $138 \mathrm{mV}$ were achieved and surface poisoning effects were avoided. ${ }^{193}$ Simultaneous voltammetric determination of dypirone and paracetamol with a carbon paste electrode was also feasible by means of multivariate calibration based on PLS. ${ }^{194}$ In other approach, the cationic surfactant cetylpyridinium bromide was used to separate the oxidation peaks of ascorbic and uric acids by $282 \mathrm{mV}$, aiming simultaneous determination of the analytes in urine samples by differential pulse voltammetry. ${ }^{195}$

Boron-doped diamond electrodes show properties notably different from those presented by electrodes of conventional materials, such as stability in aggressive alkaline and acidic media, low and stable background current and working potential range larger than 3.5 V. Electrodes of this material were applied for the simultaneous voltammetric determination of aspartame and cyclamate ${ }^{196}$ and paracetamol and caffeine, ${ }^{197}$ in view of the separation of the oxidation peak potential of 400 and $550 \mathrm{mV}$, respectively.

Other electrodes based on new materials have been also employed for the determination of pharmaceuticals. A graphite-polyurethane composite electrode was proposed for the flow-based amperometric determination of paracetamol, achieving a detection limit of $18.9 \mu \mathrm{mol} \mathrm{L}^{-1}$ and an analytical throughput of 180 determinations per hour. ${ }^{198}$
For voltammetric determination of verapamil with an electrode of this material, the detection limit was estimated as $0.7 \mu \mathrm{mol} \mathrm{L}{ }^{-1} .{ }^{199}$ Paracetamol was also determined by a biomimetic sensor prepared by a glassy carbon electrode with the surface modified with a Nafion membrane doped with FeTPyPz, which shows catalytic properties similar to the P450 enzyme. ${ }^{200}$ Electrodes prepared from mercury salts of flufenamate ${ }^{201}$ or furosemide ${ }^{202}$ were applied for potentiometric determination of the drugs in pharmaceutical preparations, clinical samples and milk. The ion-selective electrode presented fast $(<25 \mathrm{~s})$ and Nernstian responses, detection limits in the $10^{-7} \mathrm{~mol} \mathrm{~L}^{-1}$ range and lifetime of 5-6 months. A material prepared from immobilization of methylene blue on cellulose acetate modified with titanium dioxide was used in a carbon paste electrode to investigate the electrocatalytic oxidation of ascorbic acid by cyclic voltammetry and chronoamperometry. ${ }^{203}$ The voltammetric determination of pyridoxine was carried out with a glassy carbon electrode modified with chromium(III) hexacyanoferrate(II) salt. ${ }^{204}$

Rutin acts as radical scavenging and chelating for metal ions, being used as antiviral, anti-allergic and antiinflammatory. Two biosensors were developed for the determination of this flavonoid, based on hydrophobic ionic liquid containing laccase ${ }^{205}$ or a $\mathrm{Mn}^{\mathrm{III}} \mathrm{Mn}^{\mathrm{II}}$ complex as manganese peroxidase mimetic. ${ }^{206}$ Linear ranges obtained by square wave voltammetry were in the $10^{-5}$ to $10^{-6}$ range, with recoveries in the 96 to $104 \%$ interval for commercial pharmaceutical samples.

UV-Vis spectrophotometry is widely used for determination of pharmaceuticals, in view of intrinsic characteristics as low cost and robust instrumentation. These procedures are generally simple, fast and accessible, such as those proposed for determination of ceftazidime by formation of a yellow ternary complex with neocuproin and $\mathrm{Cu}(\mathrm{II}),{ }^{207}$ ritonavir by UV-derivative spectrophotometry ${ }^{208}$ and sildenafil citrate by reaction with $p$-chloranil in the presence of hydrogen peroxide. ${ }^{209}$ These characteristics are also related to the procedures based on infrared spectrometry, which are often associated to multivariate calibration. Fourier transform mid-infrared spectroscopy was used for monitoring a biotransformation reaction of 1-phenyl1,2-propanedione in a suspension of Saccharomyces cerevisiae that produces a chiral intermediate used in the synthesis of ephedrine. ${ }^{210}$ Measurements were carried out without any sample treatment and multivariate calibration by PLS allowed the determination of the substrate, reaction intermediates and the reaction product. Infrared spectrometry was also used for the determination of glucosamine and chondroitin in pharmaceutical preparations with average errors close to $1.3 \% .^{211}$ Examples 
of applications of spectrophotometric detection for drug analysis in flow systems are presented next.

Flow-based procedures have been developed for the determination of several species of pharmaceutical and clinical interest. A sequential injection analyzer coupled to a flow-batch chamber was used for the development of an analytical procedure for the spectrophotometric determination of cocaine. ${ }^{212}$ The procedure exploited the formation of a blue complex between the analyte, cobalt and thiocyanate which is extracted in chloroform and detected directly in the separation chamber. Detection limit, coefficient of variation and analytical throughput were estimated as $29 \mathrm{mg} \mathrm{L}^{-1}, 4.9 \%$ and 12 determinations per hour, respectively. The flow-batch approach was also employed for the simultaneous enzymatic determination of levedopa and carbidopa by means of data processing by PLS and the successive projections algorithm. ${ }^{213}$ The procedure was based on oxidation of the analytes to the respective dopaquinones catalyzed by polyphenol oxidase from Ipomoea batatas.

Inhibition of chemiluminescence (CL) of the luminol/ hypochlorite system by the formation of cloramines was exploited for salbutamol determination in a flow injection system. ${ }^{214}$ A liquid-core waveguide was used as reactor and flow cell in order to constrain the emitted radiation, minimizing losses during transport to detector. Detection limit, coefficient of variation and analytical throughput were estimated as $1.0 \times 10^{-7} \mathrm{~mol} \mathrm{~L}^{-1}, 2.8 \%$ and 164 determinations per hour, respectively, consuming only $50 \mu \mathrm{g}$ luminol per determination. Inhibition of CL of the luminol/hypochlorite system was further exploited for determination of paracetamol. ${ }^{215}$

Photochemical derivatization and detection by fluorescence was adopted for determination of cyclofenil ${ }^{216}$ and erythromycin ${ }^{217}$ in pharmaceuticals. The detection limits were estimated as $0.011 \mu \mathrm{mol} \mathrm{L}^{-1}$ and $25 \mu \mathrm{g} \mathrm{L}^{-1}$, respectively, with linear dynamic ranges extended up to 4 concentration decades. Luminescence was also used for determination of harmol in the presence of other carboline alkaloids by room-temperature phosphorimetry. ${ }^{218}$

A simple, fast (72 determinations per hour) and inexpensive (US\$ 2.50 per 1000 determinations) flowinjection procedure was proposed for spectrophotometric determination of captopril in pharmaceutical preparations. ${ }^{219}$ The procedure explored the on-line formation of the triiodide reagent, which is consumed by the analyte generating a transient signal, and the zone sampling approach for on-line dilutions. Reagent consumption was estimated as $18 \mu \mathrm{g}$ of $\mathrm{KMnO}_{4}$ and $10 \mathrm{mg}$ of $\mathrm{KI}$ per determination. Another flow-based procedure for determination of the anti-hypertensive used a solid-phase reactor with silver chloranilate immobilized in polyester resin and detection of the chloranilate released in the presence of the analyte by complex formation with $\mathrm{Fe}$ (III). ${ }^{220}$

A flow injection system with pulsed amperometric detection was used for simultaneous determination of paracetamol and dypirone with an analytical throughput of 45 determinations per hour. ${ }^{221}$ Simultaneous determination was carried out by fast sequentially applying potential pulses: $+0.40 \mathrm{~V}$ for detection of dypirone and $+0.65 \mathrm{~V}$ to generate the oxidation product $\mathrm{N}$-acetyl-p-benzoquinoneimine, whose reduction at $0 \mathrm{~V}$ is used for indirect determination of paracetamol.

Other applications of flow-based procedures to pharmaceuticals include the turbidimetric determination of the antidepressant amitriptyline exploring ion-pair formation with sodium lauryl sulfate, ${ }^{222}$ the expectorant agent ambroxol using a carbon film resistor electrode for amperometric detection ${ }^{223}$ and fluorimetric determination of the anti-hypertensive and diuretic furosemide in micelar medium. ${ }^{224}$

\section{Materials}

The search for new and inexpensive materials used as adsorbents is a research topic in several Brazilian research groups, mainly due to the development of new and stable stationary phases for chromatographic applications, ${ }^{225} \mathrm{pH}$ electrodes, the concern about environmental protection ${ }^{226}$ and material at nanoscale. ${ }^{227}$ Pereira et al. ${ }^{228}$ for example, prepared active carbon from coffee waste. The material was activated by $\mathrm{FeCl}_{3}$ at $280{ }^{\circ} \mathrm{C}$ and the main observed advantage was the lower temperature when compared with those procedures described in the literature. Cardoso et al. ${ }^{229}$ developed an immobilized enzyme reactor for Trypanosoma cruzi (Chagas' disease vector) metabolic studies. Glyceraldehyde-3-phosphate dehydrogenase (GAPDH) plays an important role in the life cycle of the Trypanosoma cruzi, and the authors immobilized human GAPDH for on-line screening for enzyme inhibitors. Vaz et al. ${ }^{230}$ prepared photopolymerized sol-gel monolithic columns for capillary electrochromatography and tested for separation of standard mixture containing thiourea, propylbenzene, phenanthrene and pyrene. Collins et al. ${ }^{231}$ developed a more $\mathrm{pH}$ stable stationary phase using silica layered with a metal oxide (zirconia or titania). This approach increased the HPLC column lifetime by making the stationary phase less susceptible to dissolution. Pilau et al. ${ }^{232}$ developed molecularly imprinted sol-gel silica for solid phase extraction of phenobarbital in aqueous and forensic samples. The performance of the molecularly imprinted silica (MIS) was compared with non-imprinted 
silica (NIS) and the imprinting factor (IF), measured as the ratio between phenobarbital peak areas in MIS and NIS, was estimated as 58. Silva et al. ${ }^{233}$ presented a lowcost metal oxide $\mathrm{pH}$ electrode based on the polymeric precursor method. Iridium oxide was used as the main $\mathrm{pH}$ sensitive material and it was reduced with addition of $\mathrm{TiO}_{2}$, forming a binary system $\mathrm{IrO}_{\mathrm{x}}-\mathrm{TiO}_{2}$. The proposed electrode presented Nernstian and fast response in the $\mathrm{pH}$ range from 1 to 13 and high selectivity even in presence of alkali ions as $\mathrm{Li}^{+}, \mathrm{Na}^{+}$or $\mathrm{K}^{+}$.

Quintino et al. $^{234}$ proposed a hydrazine sensor obtained by electropolymerization of meso-tetra(4-sulphonatephenyl) porphyrinate manganese (III) complex in alkaline solutions containing sub-micromolar concentrations of silver chloride. The use of nanostructured membranes was proposed by Crespilho et al. ${ }^{235}$ for glucose measurements in natural samples. The authors modified indium tin oxide glass electrodes and combined it with gold nanoparticles and poly(vinylsulfonate). Moreira et al. ${ }^{236}$ described the construction and application of two amperometric sensors for sensitive determination of $p$-aminobenzoic acid (a UVfilter) and the sensor surface characteristics was observed using atomic force microscopy (AFM).

Another scientific field being investigated is to add value to common materials like those obtained from biofuels production and commodities. ${ }^{237}$ The biomass obtained during ethanol production is an alternative for carbon sequestration being used for fuel or raw materials production. ${ }^{238}$ In this way, Cordeiro et al. ${ }^{239}$ presented a study showing morphological and physico-chemical characteristics of sugar cane bagasse ash and they suggested that this material has adequate properties to be used as pozzolan cement in construction materials. Pauliukaite et al. ${ }^{240}$ immobilized functionalized carbon nanotubes into chitosan using different cross-linking agents for hydrogen peroxide determination. The nanotube modified electrodes were characterized by cyclic voltammetry and electrochemical impedance spectroscopy. Gonçalves et al. ${ }^{241}$ studied colloidal particles that have been used to template electrosynthesis of several materials, such as semiconductors, metals and alloys. Rippel and Galembeck ${ }^{242}$ reviewed the knowledge on natural rubber and opened the way to develop a host of new nanocomposites.

The development of analytical strategies for determination of toxic elements in several materials is also an important research topic. Polymeric materials play an important role because its use in several daily products. ${ }^{243}$ Matoso and Cadore ${ }^{244}$ developed a digestion method for As, $\mathrm{B}, \mathrm{Cd}, \mathrm{Cr}, \mathrm{Cu}, \mathrm{Fe}, \mathrm{Hg}, \mathrm{Ni}, \mathrm{Pb}$ and $\mathrm{Sb}$ determination in polyvinyl acetate water emulsions. They compared classical methods like calcination, acid digestion and microwave- assisted digestion, and the most appropriate results were obtained with microwave-assisted digestion due to the lowest residual carbon content (RCC) obtained (0.1\%). Melquiades et al. ${ }^{245}$ determined titanium dioxide $\left(\mathrm{TiO}_{2}\right)$ in sunscreen formulation using energy dispersive X-ray fluorescence (EDXRF) without sample preparation and two aspects were observed: the obtained $\mathrm{TiO}_{2}$ concentrations were $10 \%$ lower than the nominal one and non cited elements like K, Zn, Br and Sr were also detected. Eguiluz et al. ${ }^{246}$ combined polymer-modified fluorine tin oxide electrodes and multiple nanoparticle labels as biosensor for Alicyclobacillus acidoterrestris in industrialized foods and beverages and it was possible to detect 2 colony forming units per $\mathrm{mL}$. Gaona-Galdos et al. ${ }^{247}$ proposed a method for determination of econazole nitrate preservatives and its main impurities in cream formulation using HPLC. Guimarães et al. ${ }^{248}$ determined free fluoride and monofluorophosphate (MFP) in toothpaste by capillary electrophoresis. The limits of detection obtained for free fluoride and MFP were 0.17 and $0.70 \mathrm{mg} \mathrm{L}^{-1}$, respectively. Silvério et al. ${ }^{249}$ characterized synthetic polymers and speck impurities in cellulose pulp using pyrolysis-gas chromatography-mass spectrometry (Py-GC/MS) and Fourier transform infrared spectroscopy (FT-IR). Authors concluded that Py-GC/MS was more efficient in the differentiation between impurities when compared to FT-IR.

The development of methods for quality control of pharmaceuticals is also an area with important contributions from Brazilian analytical chemistry. Cervini and Cavalheiro ${ }^{250}$ proposed a bare graphite-polyurethane composite as an amperometric detector for determination of atenolol in pharmaceutical formulations. Paracetamol was molecularly imprinted (MIP) in methacrylate polymer and after paracetamol extraction, the MIP's were incorporated into a graphite-polyurethane matrix..$^{251}$ The resulting composites were used to prepare modified electrodes intended to be used in paracetamol determination. The obtained results were compared with HPLC and no statistical difference was observed at a confidence level of $95 \%$.

\section{Chemometrics}

Application of chemometrics in analytical chemistry is a reality in Brazil and studies were carried out in several areas like electroanalysis, ${ }^{252}$ structure-activity relationships (QSAR) $)^{253}$ and mass spectrometry. ${ }^{254}$ The use of optimization strategies such as response surface methodology (RSM) is useful due to the number of studied variables and to obtain information with a low number of experiments. ${ }^{255}$ 
Bueno studied the antagonic effect of $\mathrm{Fe}$ and $\mathrm{Zn}$ in formulations of feeding diets employing mixture design and RSM. ${ }^{256}$ The combination of factorial design and Varimax factor optimization can lead to interesting results in chromatographic parameters investigation. Soares et al. ${ }^{257}$ for example, used this approach to optimize a mixture of dichloromethane, hexane, ethanol and acetone in compounds extracted from Erythrina speciosa Andrews leaves. Paim et al. ${ }^{258}$ optimized a UV spectrophometric method for the determination of entacapone in tablets and the results were compared with HPLC. A preconcentration and speciation method for $\mathrm{Sb}(\mathrm{III})$ and $\mathrm{Sb}(\mathrm{V})$ was proposed by Souza and Tarley. ${ }^{259}$ Cloud point extraction was used and the analytical parameters were optimized by multivariate design.

When a large number of variables need to be screened a fractional factorial design is alternative combining a small number of experiments and a quick identification of the most significant variables. Uliana et al. ${ }^{260}$ used fractional factorial design for development of an amperometric biosensor for detection of the hepatitis $C$ virus. Santos and Masini used RSM to study four variables for optimization of $\mathrm{Cu}$ phthalocyanine photo-Fenton degradation. ${ }^{261} \mathrm{In}$ spectroanalysis field Lara et al. ${ }^{262}$ optimized GFAAS parameters for direct Mn determination in breast milk.

Nowadays it is possible to obtain a great variety and quantity of analytical data and exploratory analysis is a useful way to have a global vision from the data set. Andrade et al. ${ }^{263}$ used principal component analysis (PCA) and hierarchical cluster analysis (HCA) to evaluate physico-chemical parameters in samples of red wines. They concluded that $\mathrm{pH}$, chloride concentration, color and ammonium content were the most important variables for sample classification. Santos et al. ${ }^{264}$ determined several metals using ICP OES and ETAAS in water and sediments and the results were analyzed using exploratory statistical tools. The authors observed that the aquatic system presented suitable conditions to move $\mathrm{Cd}^{2+}$ and $\mathrm{Pb}^{2+}$ from the water column to the sediment. Godinho et al. ${ }^{265}$ proposed a classification model of carbonated soft drink based on image analysis and PCA. Using this approach it was possible to correlate $\mathrm{pH}$, sorbic acid and sucrose concentrations with the images. Soft drinks were also investigated by Froes et al. ${ }^{266}$ using ICP OES and PCA. The operational conditions of the ICP were optimized using factorial design and 13 elements were determined. Using PCA these authors identified 4 clusters related to flavor, light, diet and low calorie. Honey samples from semi-arid, Atlantic and transitional forest zones in Bahia (Brazil) were characterized based on their mineral and trace elements, ash content and electrical conductivity. ${ }^{267}$ Reche and Franco ${ }^{268}$ used chemometric tools to analyze chromatographic and metal composition of cachaças distilled in pot stills and in columns. Panero and Silva ${ }^{269}$ applied PCA and HCA to characterize groundwater used for the public supply of potable water in the Roraima State (Brazil). The authors observed a clear distinction between groundwater with and without bicarbonate. Zimmermann et $a l^{270}$ evaluated water samples obtained from Tibagi River (Paraná State, Brazil) using PCA and observed that the industrial activity contributed to raise the total concentration of amoniacal nitrogen and the reduction of dissolved oxygen in the studied region. Pontes et al. ${ }^{271}$ proposed classification models to study Brazilian soils using LIBS (laser-induced breakdown spectroscopy) and linear discriminant analysis (LDA). The authors compared three techniques for variable selection: successive projection algorithm (SPA), genetic algorithm (GA) and stepwise formulation (SW). Exploratory analysis can be also combined with chromatographic data set and Risticevic et al. ${ }^{272}$ studied the geographical origin of coffee samples using headspace solid-phase microextraction and gas chromatographic-time-of-flight mass spectrometry. Schiozer et al. ${ }^{273}$ used PCA to predict the number of Arrabidaea chica species presented in liquid extracts. This substance is rich in compounds that are potential alternative natural pigments for food and cosmetics. Moreira et al. ${ }^{274}$ used near-infrared reflectance spectrometry (NIRS) and successive projections algorithm to propose a cigarettes classification model. Using this combination the authors were able to differentiate the cigarettes in four brands.

Spectrometric techniques like NIR are able to produce in a short period of time a huge quantity of spectra that usually are processed by multivariate calibration. Determination of gasoline quality parameters, for example, are time consuming and Pereira et al. ${ }^{275}$ proposed a combination of NIR and chemometric tools for naphthenes and RON (research octane number) determination. In addition, the authors made a comparative study of calibration transfer methods using three different near-infrared spectrometers. Valderrama and Poppi $^{276}$ proposed a method using molecular fluorescence for quantification of propranolol enatiomers. The authors compared two chemometric techniques and observed that bilinear least squares (BLLS) presented low relative mean error than parallel factor analysis (PARAFAC). Trevisan $e t$ al. ${ }^{277}$ monitored biodiesel production using mid-infrared spectroscopy and PLS. Evolving factor analysis (EFA) was used to overcome the sensor time delay due to the on-line analysis. Godoy et al. ${ }^{278}$ proposed a method for kerosene quantification in gasoline using two-dimensional gas chromatography and the best results were obtained using NPLS (Multi-way PLS). Mello et al. ${ }^{279}$ proposed a fast method to differentiate bacteria causing pharyngitis and low resolution raman spectroscopy (LRRS). The classical 
microbiological method for diagnosis of bacteria that cause pharyngitis has a high cost of reagents and is timeconsuming. With the proposed method the microorganisms are dispersed using physiological solution and Raman spectra of these dispersions were recorded using a diode laser operating in the near region. PLS-discriminant analysis (PLS-DA) was able to obtain $100 \%$ correct classification.

Hernández et al. ${ }^{280}$ showed that support vector regression for functional data (FDA-SVR) is an effective and promising tool for multivariate calibration problems. Alves and Poppi ${ }^{281}$ proposed a method for simultaneous determination of acetylsalicylic acid, paracetamol and caffeine using solid-phase molecular fluorescence and PARAFAC. Valderrama and Poppi ${ }^{282}$ presented a method for propranolol enantiomers determination in plasma and urine using spectrofluorimetry, second-order standard additions method and the combined strategy of PARAFAC with the standard additions method.

The wavelet signal processing method was applied to minimize noisy signals and for simultaneous determination of $\mathrm{Cu}$ and $\mathrm{Pb}$ in water samples by potentiometric striping analysis. ${ }^{283}$ Results obtained with a lab-made low-cost potentiostat agreed with those attained using commercial equipment, with coefficient of variation lower than $3 \%$.

\section{Instrumentation and Automation}

Contributions of Brazilian authors related to development of instrumentation have focused mainly on ingenious alternatives for designing low-cost equipments or apparatus. In this sense, inexpensive, portable and microcontroled photometers based on light emitting diodes were proposed for measurements at near-infrared ${ }^{284}$ and visible ${ }^{285}$ spectral regions. The infrared photometer used a LED with maximum emission at $1550 \mathrm{~nm}$ and a $\mathrm{PbSe}$ photoresistor as radiation source and detector, respectively. A temperature sensor (thermoresistor) and a thermoelectric cooling system were incorporated to minimize the detector noise, improving the equipment performance. The photometer was applied for screening analysis of gasoline after establishing suitable thresholds values to minimize false negative adulteration down to $5 \%$. The spectrophotometer for measurements in the visible region was based on a white LED and a phototransistor as phototransductor. A compact disk (CD) media movable by a stepper motor was used as diffraction grid. Equipment performance was evaluated by determination of food colorants in synthetic samples and $\mathrm{Fe}$ (II) in restorative oral solutions, with results in agreement with those obtained by commercial spectrophotometers. Operation of both equipments was controlled by a programmable interrupt controller (PIC), which also allowed data acquisition and presentation of the results on a liquid crystal display.

An interesting work proposed the use of digital images captured by a webcam for quantification of metal ions by FAES. ${ }^{286}$ The analytical signal was obtained from a vector related to the red-green-blue color system associated to the analyte emission, yielding linear calibration curves. The proposed approach was successfully applied to the determination of $\mathrm{Li}, \mathrm{Na}$, and $\mathrm{Ca}$ in anti-depressive drugs, physiological serum and water, respectively, with analytical features better than the achieved by conventional flame photometric detection. A similar approach was adopted in a didactic experiment exploiting the digital image produced by a scanner for quantification of ascorbic acid by molecular absorption spectrophotometry. ${ }^{287}$

Other main trend of the researches in instrumentation in Brazil is the development of miniaturized devices, especially following innovative and low cost technologies. A monolithic flow microanalyzer ( $\mu$ TAS) with amperometric detection was designed and fabricated, incorporating the microfluidics, the complete detection system and the associated electronics in a single micro-device $(5.3 \times 10.4 \times 0.3 \mathrm{~cm}){ }^{288} \mathrm{In}$ order to overcome its main limitation, the working electrode is changeable in function of the analytical application or when its surface is passivated or poisoned. The performance of the micro-device was evaluated using detection of hexacyanoferrate(III) or free chlorine as model systems and signal-to-noise ratios were comparable to those obtained with conventional instrumentation. Disposable electrochemical micro-cells incorporating working, reference and auxiliary electrodes on a single device were constructed by means of thermaltransfer of toner masks to gold surfaces obtained from recordable CDs. ${ }^{289}$ Preparation of the micro-cells was very reproducible, with a relative standard deviation of the electrodes area better than $1.0 \%(n=10)$. In another work, a three electrode electrochemical microfluidic cell was proposed and characterized. ${ }^{290}$ The electrodes were inserted in microchannels with lower than $20 \mu \mathrm{m}$ thickness, constructed between two polycarbonate slides, using toner masks as spacer. Internal volume was within the 0.6 to $2.5 \mu \mathrm{L}$ range and analytical performance was evaluated by means of cyclic voltammetry, potentiometric stripping analysis and square wave anodic stripping voltammetry. Ultramicroelectrodes for detection by coulometry or amperometry in flowing systems were also developed. ${ }^{291}$ The applicability was demonstrated by measurement of glucose and glycine in a flow-based system and of glyphosate, coupling the detector to a HPLC system.

A near-infrared spectropolarimeter was designed with a noncollinear acousto-optical tunable filter (AOTF) to avoid 
the use of mechanical parts and simplify the acquisition of optical rotational spectra. ${ }^{292}$ The AOTF was based on an anisotropic crystal of $\mathrm{TeO}_{2}$ that yields rotation of the polarization plane in the presence of an optically active sample. The double-beam configuration was adopted to compensate the effects of fluctuations in the power of radiation source. Instrumental performance was evaluated with aqueous solutions of sucrose, glucose, and fructose and for D, L and DL camphor.

Brazil was one of the pioneers in flow analysis and researches in this field remain traditional in our country. Several applications were described in previous items. In addition, a sequential injection analysis (SIA) system was used for optimization of Fenton process for degradation of pigments used in coating industry. Solution aliquots were on-line sampled from the reactor and optimization was based on reduction of the color of the dye using the response surface methodology. ${ }^{293}$ The versatility of SIA and the separation capability provided by liquid chromatography with monolithic columns have been coupled in sequential injection chromatography. A procedure based on this approach was developed for determination of intracellular free amino acids in the green alga Tetraselmis gracilis with fluorimetric detection after pre-column derivatization. ${ }^{294}$ Stepwise elution (5 isocratic steps) allowed the successful separation (resolution higher than 1.2) of 14 amino acids in $25 \mathrm{~min}$, with detection limits ranging from 0.09 to $0.5 \mu \mathrm{mol} \mathrm{L}{ }^{-1}$. Aiming at routine analysis, a low cost autosampler for flow injection analysis was designed with two stepper motors obtained from discarded floppy disks drives. ${ }^{295}$

Fundamental aspects related to flow analysis have also been focused, such as investigation of the characteristics of the pulsed-flow inherent to the multi-pumping flowsystems. ${ }^{296}$ Evidences of turbulent flow were found by the authors, based on peak shapes and photographic images. Vortices produced by the actuation of the solenoid micropumps contribute to enhance radial mass transport and to avoid solid deposition as previously mentioned. ${ }^{108}$

Hyphenation of a flow injection system to capillary electrophoresis was exploited for on-line preconcentration on an anionic resin column. ${ }^{297}$ Sensitivity improvement was estimated as $660 \%$, without critically affecting resolution (peak dispersion increased in $8 \%$ ).

Long pathlength cells based on liquid core waveguides are an alternative to improve sensitivity in UV-Vis spectrophotometry, yielding detection limits in the $\mathrm{nmol} \mathrm{L}^{-1}$ range. The performance of a flow cell based on this principle was critically evaluated for measurements in flow systems, including monosegmented flow and turbidimetric measurements. ${ }^{298}$ The magnitude of the Schlieren effect was up to $40 \%$ higher than the observed in conventional $1 \mathrm{~cm}$ cells, which is quite lower than the gain in sensitivity in view of the increase in the optical path. The drawback was effectively compensated by dual-wavelength spectrophotometry. The construction of low-cost lab-made flow cells based on liquidcore waveguides was also proposed. ${ }^{299,300}$

A semi-continuous analyzer based on two concentric tubes was proposed for fluorimetric determination of atmospheric formaldehyde. ${ }^{301}$ The air sample was continually pumped through the external tube and the analyte was collected in a central microporous PTFE tube filled with the Fluoral-P reagent. Under optimized conditions defined by the Box-Behnken design, the detection limit and coefficient of variation were estimated as $0.55 \mathrm{ng} \mathrm{L}^{-1}$ and $8.6 \%$, respectively.

A simple system for pressurized solvent extraction was designed aiming fast extractions, reducing both reagent consumption and risks of analyte decomposition. ${ }^{302}$ The main components were a pneumatic pump and stainless steel extraction cells of several sizes, with the use of nitrogen gas for pressurization. The performance was evaluated by the extraction of herbicides from polluted soil and soybean oil, being the results compared with the attained by soxhlet and solid-phase extraction, respectively.

\section{Final Remarks}

The selected publications demonstrated the evolution of analytical chemistry in Brazil in major applications areas. The increase in the cumulative citations during this decade is shown in Figure 3. The progress of number of papers (Figure 4) and number of cumulative citations (Figure 5) in major areas of chemistry also show the sustaining growth of analytical chemistry and other areas. However, it should be pointed out that comparisons among areas must be done cautiously because the data are only quantitative and the number of researchers working in each area and their specificities were not considered. The relatively smooth curve in the last years may be related to the fast growing in the past decade and in the first years of this decade, and may indicate that further acceleration will depend on formation of new human resources and continuous investment in analytical chemistry. Surely the analytical chemistry community is willing to keep moving forward as recently demonstrated in the $15^{\text {th }}$ National Meeting in Analytical Chemistry held in Salvador, Bahia, from 18 to 21 , October. This meeting was attended by 900 participants that presented 890 communications in crowded poster and oral sessions. It may be concluded that analytical chemistry in Brazil is healthy and growing, and is ready to support the new role of the country as an emerged power. ${ }^{303}$ 


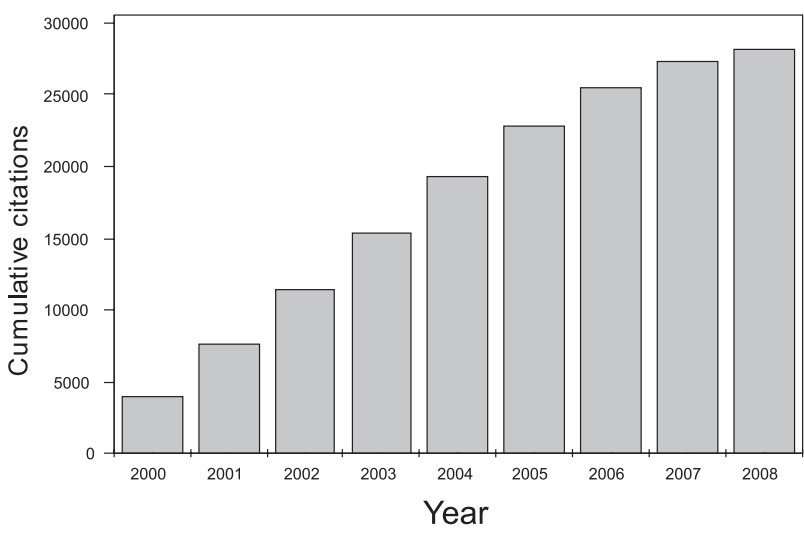

Figure 3. Evolution of citation of papers published by Brazilian authors in analytical chemistry. Data in successive years are cumulative.

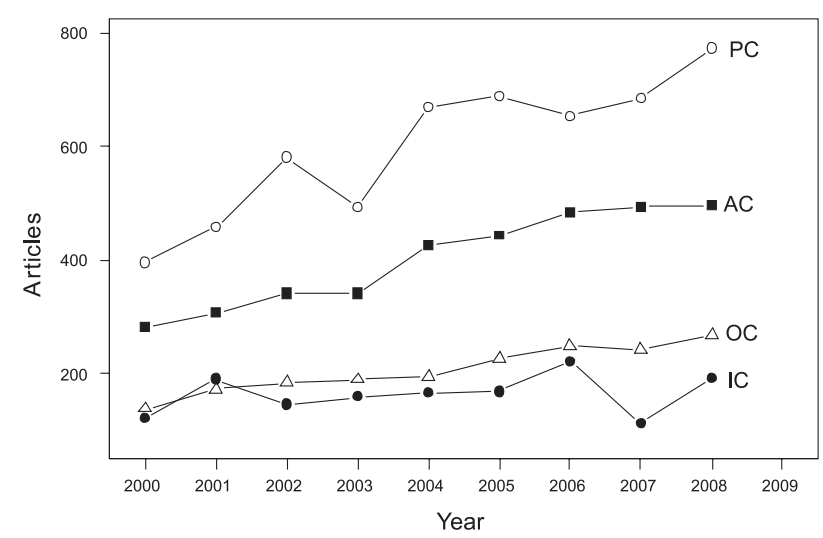

Figure 4. Number of papers published by Brazilian authors in physical chemistry (PC), analytical chemistry (AC), organic chemistry (OC), and inorganic chemistry (IC).

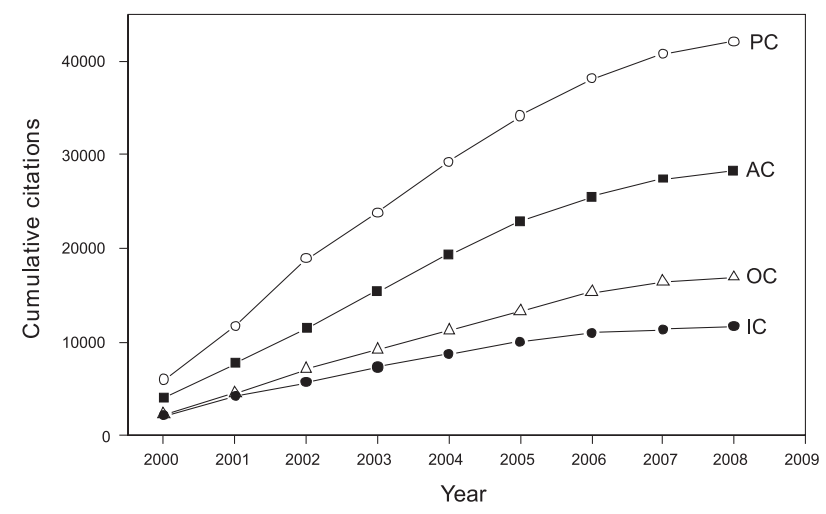

Figure 5. Number of cumulative citations for papers published by Brazilian authors in physical chemistry (PC), analytical chemistry (AC), organic chemistry (OC), and inorganic chemistry (IC).

\section{Acknowledgments}

The authors would like to thank the Editor, Prof. Jailson B. De Andrade, of the Journal of the Brazilian
Chemical Society for the invitation for writing this review. The authors also express their gratitude to the Brazilian agencies Fundação de Amparo à Pesquisa do Estado de São Paulo (FAPESP), Conselho Nacional de Desenvolvimento Científico e Tecnológico (CNPq), and Coordenação de Aperfeiçoamento de Pessoal de Nível Superior (CAPES) for continuous support to research activities.

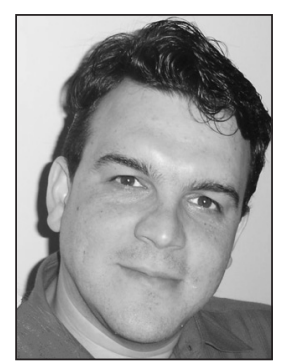

Fábio R. P. Rocha is graduated in chemistry at the University Federal of São Carlos where he also concluded his MSc and PhD programs working with automation in Analytical Chemistry. He is Associate Professor of the Chemistry Institute of University of São Paulo and nowadays is acting as Director of the Division of Analytical Chemistry of the Brazilian Chemical Society. His research is focused on instrumentation and automation in Analytical Chemistry, flow-based and optical methods of analysis.

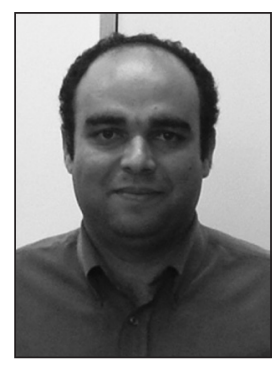

Edenir R. Pereira-Filho received his Ph.D. from the State University of Campinas (2003). He is Adjunct Professor in the Department of Chemistry at the University Federal of São Carlos (UFSCar). His research interests are atomic absorption spectrometry and chemometrics applications in analytical chemistry.

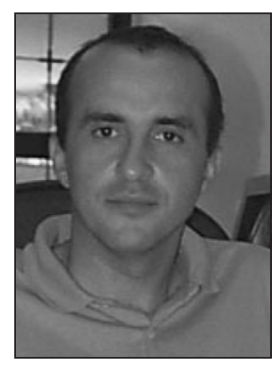

Joaquim A. Nóbrega received his Ph.D. from the State University of Campinas (1992) and completed his postdoctoral trainings with $\mathrm{Dr}$. Ramon M. Barnes (University of Massachusetts, Amherst, MA, 1996) and with Dr. Bradley T. Jones (Wake Forest University, Winston-Salem, NC, 2003). He is Associate Professor in the Department of Chemistry at the University Federal of São Carlos. His research interests are sample preparation for inorganic analysis, atomic absorption spectrometry, atomic emission spectrometry, and inductively coupled plasma mass spectrometry. He is a member of the Brazilian Society of Chemistry, American Chemical Society, and The Royal Society of Chemistry. 


\section{References}

1. De Andrade, J. B.; Korn, M. G. A.; Cadore, S.; Microchem. J. 2004, 77, 101.

2. Ferreira, S. L. C.; Pereira, P. A. P.; Nóbrega, J. A.; Fatibello-Filho, O.; Feres, M. A.; Reis, B. F.; Bruns, R. E.; Aquino Neto, F. R.; Anal. Lett. 2008, 41, 1494.

3. Pasquini, C; Cortez, J.; Silva, L. M. C.; Gonzaga, F. B.; J. Braz. Chem. Soc. 2007, 18, 463.

4. Trevizan, L. C.; Nóbrega, J. A.; J. Braz. Chem. Soc. 2007, 18, 678.

5. Valderrama, P.; Braga, J. W. B.; Poppi, R. J.; J. Braz. Chem. Soc. 2007, 18, 259.

6. Corrêa, S. M.; Arbilla, G.; J. Braz. Chem. Soc. 2007, 18, 539.

7. Silva, T. F.; Azevedo, D. A.; Aquino Neto, F. R.; J. Braz. Chem. Soc. 2007, 18, 628.

8. Bisinoti, M. C.; Sargentini Jr., E.; Jardim. W. F.; J. Braz. Chem. Soc. 2007, 18, 544.

9. Rodrigues, M. V. N.; Reyes, F. G. R.; Magalhães, P. M.; Rath, S.; J. Braz. Chem. Soc. 2007, 18, 135.

10. Lopes, M. V.; Korn, M.; Pereira, M. G.; Santana, E. P.; Oliveira, F. S.; Korn, M. G. A.; J. Braz. Chem. Soc. 2007, 18, 703.

11. Torres, D. P.; Vieira, M. A.; Ribeiro, A. S.; Curtius, A. J.; J. Braz. Chem. Soc. 2007, 18, 728.

12. Flores, E. M. M.; Barin, J. S.; Paniz, J. N. G.; Medeiros, J. A.; Knapp, G.; Anal. Chem. 2004, 76, 3525.

13. Barin, J. S.; Bartz, F. R.; Dressler, V. L.; Paniz, J. N. G.; Flores, E. M. M.; Anal. Chem. 2008, 80, 9369.

14. Castro, J. T.; Santos, E. C.; Santos, W. P. C.; Costa, L. M.; Korn, M.; Nóbrega, J. A.; Korn, M. G. A.; Talanta 2009, 78, 1378.

15. Gonzalez, M. H.; Souza, G. B.; Oliveira, R. V.; Forato, L. A.; Nóbrega, J. A.; Nogueira, A. R. A.; Talanta 2009, 79, 396.

16. Souza, G. B.; Menezes, E. A.; Gonzalez, M. H.; Carapelli, R.; Cheves, F. S.; Matos, W. O.; Nogueira, A. R. A.; Anal. Lett. 2008, 41, 1633.

17. Santos, W. P. C.; Gramacho, D. R.; Teixeira, A. P.; Costa, A. C. S.; Korn, M. G. A.; J. Braz. Chem. Soc. 2008, 19, 1.

18. Nano, R. M. W.; Bruns, R. E.; Ferreira, S. L. C.; Baccan, N.; Cadore, S.; Talanta 2009, 80, 559.

19. Carvalho, L. M.; Spengler, C.; Garmatz, J. C.; Nascimento, P. C.; Del-Fabro, L.; Radis, G.; Bolli, A. A.; Garcia, S. C.; Moro, A. M.; Rosa, M. B.; Quim. Nova 2008, 31, 1336.

20. Santos, W. P. C.; Hatje, V.; Lima, L. N.; Trignano, S. V.; Barros, F.; Castro, J. T.; Korn, M. G. A.; Microchem. J. 2008, 89, 123.

21. Giné, M. F.; Patreze, A. F.; Silva, E. L.; Sarkis, J. E. S.; Kakazu, M. H.; J. Braz. Chem. Soc. 2008, 19, 471.

22. Andrade, F. P.; Nascentes, C. C.; Costa, L. M.; J. Braz. Chem. Soc. 2009, 20, 1460.

23. Gomes, M. S.; Pereira-Filho, E. R.; Microchem. J. 2009, 93, 93.

24. Donati, G. L.; Pharr, K. E.; Calloway Jr., C. P.; Nóbrega, J. A.; Jones, B. T.; Talanta 2008, 76, 1252.
25. Santos, E. J.; Herrmann, A. B.; Frescura, V. L. A.; Sturgeon, R. E.; Curtius, A. J.; J. Braz. Chem. Soc. 2008, 19, 929.

26. Kehrig, H. A.; Seixas, T. G.; Palermo, E. A.; Di Beneditto, A. P. M.; Souza, C. M. M.; Malm, O.; Anal. Lett. 2008, 41, 1691.

27. Welz, B.; Becker-Ross, H.; Florek, S.; Heitmann, U.; Vale, M. G. R.; J. Braz. Chem. Soc. 2003, 14, 220.

28. Santos, L. M.; Gonçalves, J. M.; Jacob, S. M.; Quim. Nova 2008, $31,975$.

29. Batista, B. L.; Rodrigues, J. L.; Nunes, J. A.; Souza, V. C. O.; Barbosa Jr., F.; Anal. Chim. Acta 2009, 639, 13.

30. Batista, B. L.; Grotto, D.; Rodrigues, J. L.; Souza, V. C. O.; Barbosa Jr., F.; Anal. Chim. Acta 2009, 646, 23.

31. Batista, B. L.; Rodrigues, J. L.; Tormen, L.; Curtius, A. J.; Barbosa Jr., F.; J. Braz. Chem. Soc. 2009, 20, 1406.

32. Belaz, K. R. A.; Cass, Q. B.; Oliveira, R. V.; Talanta 2008, 76, 146.

33. Magalhães, I. R. S.; Bonato, P. S.; Anal. Bioanal. Chem. 2009 , 393, 1805.

34. Figueiredo, E. C.; Oliveira, D. M.; Siqueira, M. E. P. B.; Arruda, M. A. Z.; Anal. Chim. Acta 2009, 635, 102.

35. Santos, W. J. R.; Lima, P. R.; Tarley, C. R. T.; Höehr, N. F.; Kubota, L. T.; Anal. Chim. Acta 2009, 631, 170.

36. Melo, L. P.; Nogueira, A. M.; Lanças, F. M.; Queiroz, M. E. C.; Anal. Chim. Acta 2009, 633, 57.

37. Paixão, T. R. L. C.; Barbosa, L. F.; Carri, M. T.; Medeiros, M. H. G.; Bertotti, M.; Analyst 2008, 133, 1605.

38. Kubota, L. T.; Torresi, R. M.; J. Braz. Chem. Soc. 2008, 19(4), vi.

39. Galembeck, F.; Pardini, V. L.; Quim. Nova 2009, 32, 565.

40. Gonçalves, A. M.; Fernandes, K. G.; Ramos, L. A.; Cavalheiro, E. T. G.; Nóbrega, J. A.; J. Braz. Chem. Soc. 2009, $20,760$.

41. Souza, M. G.; Vieira, E. C.; Oliveira, P. V.; Quim. Nova 2009, $32,1442$.

42. Boen, T. R.; Soeiro, B. T.; Pereira-Filho, E. R.; Lima-Pallone, J. A.; J. Braz. Chem. Soc. 2008, 19, 53.

43. Araújo, R. G. O.; Macedo, S. M.; Korn, M. G. A.; Pimentel, M. F.; Bruns, R. E.; Ferreira, S. L. C.; J. Braz. Chem. Soc. 2008, 19, 935.

44. Martins-Júnior, H. A.; Wang, A. Y.; Alabourda, J.; Pires, M. A. F.; Vega, O. B.; Lebre, D. T.; J. Braz. Chem. Soc. 2008, 19, 971.

45. Araujo, R. G. O.; Oleszczuk, N.; Rampazzo, R. T.; Costa, P. A.; Silva, M. M.; Vale, M. G. R.; Welz, B.; Ferreira, S. L. C.; Talanta 2008, 77, 400 .

46. Santos, L. M. G.; Araujo, R. G. O.; Welz, B.; Jacob, S. C.; Vale, M. G. R.; Becker-Ross; Talanta 2009, 78, 577.

47. Nomura, C. S.; Intima, D. P.; Oliveira, P. V.; Ruffini, I. A.; Krug, F. J.; Anal. Bioanal. Chem. 2008, 391, 1135.

48. Mendes, R. K.; Ferreira, D. C. M.; Carvalhal, R. F.; Peroni, L. A.; Stach-Machado, D. R.; Kubota, L. T.; J. Braz. Chem. Soc. 2009, 20, 795 .

49. César, I. C.; Braga, F. C.; Vianna-Soares, C. D.; Nunan, E. A.; Pianetti, G. A.; Moreira-Campos, L. M.; Quim. Nova 2008, 31, 1933. 
50. Martin, C. A.; Visentainer, J. V.; Oliveira, A. N.; Oliveira, C. C.; Matsushita, M.; Souza, N. E.; J. Braz. Chem. Soc. 2008, 19, 117.

51. Amorim, A. C. L.; Hovell, A. M. C.; Pinto, A. C.; Eberlin, M. N.; Arruda, N. P.; Pereira, E. J.; Bizzo, H. R.; Catharino, R. R.; Morais Filho, Z. B.; Rezende, C. M.; J. Braz. Chem. Soc. 2009, 20, 313.

52. Jham, G. N.; Berkow, M. A.; Manthey, L. K.; Palmquist, D. A.; Vaughn, S. F.; J. Braz. Chem. Soc. 2008, 19, 1462.

53. Ribeiro, J. S.; Augusto, F.; Salva, T. J. G.; Thomaziello, R. A.; Ferreira, M. M. C.; Anal. Chim. Acta 2009, 634, 172.

54. Medeiros, R. A.; Carvalho, A. E.; Rocha-Filho, R. C.; FatibelloFilho, O.; Quim. Nova 2008, 31, 1405.

55. Soares, F. B.; Sousa, J. M.; Dimenstein, R.; Quim. Nova 2008, $31,268$.

56. Goulart, S. M.; Queiroz, M. E. L. R.; Neves, A. A.; Queiroz, J. H.; Talanta 2008, 75, 1320.

57. Kolberg, D. I. S.; Presta, M. A.; Wickert, C.; Adaime, M. B.; Zanella, R.; J. Braz. Chem. Soc. 2009, 20, 1220.

58. Andrade, L. S.; Moraes, M. C.; Rocha-Filho, R. C.; FatibelloFilho, O.; Cass, Q. B.; Anal. Chim. Acta 2009, 654, 127.

59. Scherer, R.; Rybka, A. C. P.; Godoy, H. T.; Quim. Nova 2008, $31,1137$.

60. Boa Morte, E. S.; Korn, M. G. A.; Saraiva, M. L. M. F. S.; Lima, J. L. F. C.; Talanta 2009, 79, 1100.

61. Assis, R. A.; Küchler, I. L.; Miekeley, N.; Silveira, C. L. P.; Quim. Nova 2008, 31, 1948.

62. Ferreira, S. L. C.; Silva, E. G. P.; Portugal, L. A.; Matos, G. D.; Santana, F. A.; Korn, M. G. A.; Costa, A. C. S.; Anal. Lett. 2008, 41, 1571.

63. Schiavo, D.; Neira, J. Y.; Nóbrega, J. A. Talanta 2008, 76, 1113.

64. Ferreira, S. L. C.; Jesus, R. M.; Matos, G. D.; De Andrade, J. B.; Bruns, R. E.; Santos, W. N. L.; Cavalcante, D. D.; Vale, M. G. R.; Dessuy, M. B.; J. Braz. Chem. Soc. 2009, 20, 788.

65. Dessuy, M. B.; Vale, M. G. R.; Souza, A. S.; Ferreira, S. L. C.; Welz, B.; Katskov, D. A.; Talanta 2008, 74, 1321.

66. Ferreira, S. L. C.; Souza, A. S.; Brandão, G. C.; Ferreira, H. S.; Santos, W. N. L.; Pimentel, M. F.; Vale, M. G. R.; Talanta 2008, 74, 699.

67. Fernandes, S. C.; Osório, R. E-H. M. B.; Anjos, A.; Neves, A.; Micke, G. A.; Vieira, I. C.; J. Braz. Chem. Soc. 2008, 19, 1215.

68. Santini, A. O.; Lemos, S. C.; Pezza, H. R.; Carloni-Filho, J.; Pezza, L.; Microchem. J. 2008, 90, 124.

69 Moya, H. D.; Dantoni, P.; Rocha, F. R. P.; Coichev, N.; Microchem. J. 2008, 88, 21.

70. Galinaro, C. A.; Franco, D. W.; Quim Nova 2009, 32, 1447.

71. Caruso, M. S. F.; Alaburda, J.; J. Braz. Chem. Soc. 2009, $20,502$.

72. Andrade Sobrinho, L. G.; Cappelini, L. T. D.; Silva, A. A.; Galinaro, C. A.; Buchviser, S. F.; Cardoso, D. R.; Franco, D. W.; Quim. Nova 2009, 32, 116.

73. Labanca, R. A.; Glória, M. B. A.; Afonso, R. J. C. F.; Quim. Nova 2008, 31, 1860 .
74. Cardeal, Z. L.; Souza, P. P.; Silva, M. D. R. G.; Marriott, P. J.; Talanta 2008, 74, 793.

75. Penteado, J. C. P.; Sobral, A. C.; Masini, J. C.; Anal. Lett. 2008, 41, 1674.

76. Caldas, N. M.; Oliveira, S. R. O.; Gomes Neto, J. A.; Anal. Chim. Acta 2009, 636, 1.

77. Lowinsohn, D.; Bertotti, M.; J. Braz. Chem. Soc. 2008, 19, 637.

78. Biazon, C. L.; Brambilla, R.; Rigacci, A.; Pizzolato, T. M.; Santos, J. H. Z.; Anal. Bioanal. Chem. 2009, 394, 549.

79. Souza, B. A.; Marchini, L. C.; Oda-Souza, M.; Carvalho, C. A. L.; Alves, R. M. O.; Quim. Nova 2009, 32, 303.

80. Carpes, S. T.; Prado, A.; Moreno, I. A. M.; Mourão, G. B.; Alencar, S. M.; Masson, M. L.; Quim. Nova 2008, 31, 1660.

81. Franchini, R. A. A.; Matos, M. A. C.; Colombara, R.; Matos, R. C.; Talanta 2008, 75, 301.

82. Jardim, I. C. S. F.; Andrade, J. A.; Queiroz, S. C. N.; Quim. Nova 2009, 32, 996.

83. Granja, R. H. M. M.; Montes Nino, A. M.; Rabone, F.; Salerno, A. G.; Anal. Chim. Acta 2008, 613, 116.

84. Granja, R. H. M.; Montes Nino, A. M.; Zucchetti, R. A. M.; Montes Nino, R. E.; Patel, R.; Salerno, A. G.; Anal. Chim. Acta 2009, 637, 64.

85. Santos, T. F. S.; Aquino, A.; Dórea, H. S.; Navickiene, S.; Anal. Bioanal. Chem. 2008, 390, 1425.

86. Abreu, A. B. G.; Matta, M. H. R.; Montagner, E.; Quim. Nova 2008, 31,5 .

87. Pinho, G. P.; Neves, A. A.; Queiroz, M. E. L. R.; Quim. Nova 2009, 32, 92 .

88. Kurz, M. H. S.; Gonçalves, F. F.; Adaime, M. B.; Costa, I. F. D.; Primel, E. G.; Zanella, R.; J. Braz. Chem. Soc. 2008, 19, 1129.

89. Pereira, L. A.; Rath, S.; Anal. Bioanal. Chem. 2009, 393, 1063.

90. Silva; M. G. D.; Aquino, A.; Dórea, H. S.; Navickiene, S.; Talanta 2008, 76, 680 .

91. Maffei, D. F.; Nogueira, A. R. A.; Brondi, S. H. G.; Quim. Nova 2009, 32, 1713.

92. Matos Reyes, M. N.; Luisa Cervera, M.; Campos, R. C.; Guardia, M.; Talanta 2008, 75, 811.

93. Bergmann, J.; González, A.; Zarbin, P. H. G.; J. Braz. Chem. Soc. 2009, 20, 1206

94. Silva, G. S.; Bisinoti, M. C.; Fadini, P. S.; Magarelli, G.; Jardim, W. F.; Fostier, A. H.; J. Braz. Chem. Soc. 2009, 20, 1127.

95. Kehrig, H. A.; Palermo, E. F. A.; Seixas, T. G.; Santos, H. S. B.; Malm, O.; Akagi, H.; J. Braz. Chem. Soc. 2009, 20, 1142.

96. Santos, J. S.; Guardia, M.; Augustin P.; Santos, M. L. P.; Talanta 2009, 80, 207.

97. Oliveira, E. P.; Santelli, R. E.; Cassella, R. J.; Microchem. J. 2008, 89, 116.

98. Carbo, L.; Souza, V.; Dores, E. F. G. C.; Ribeiro, M. L.; J. Braz. Chem. Soc. 2008, 19, 1111.

99. Pinheiro, A. S.; De Andrade, J. B.; Talanta 2009, 79, 1354. 
100. Sabin, G. P.; Prestes, O. D.; Adaime, M. B.; Zanella, R.; J. Braz. Chem. Soc. 2009, 20, 918.

101. Rodrigues, G. D.; Lemos, L. R.; Silva, L. H. M.; Silva, M. C. H.; Minim, L. A.; Coimbra, J. S. R.; Talanta 2009, in press.

102. Santos, L. B. O.; Masini, J. C.; Anal. Chim. Acta 2008, 606, 209.

103. Nascimento, P. C.; Jost, C. L.; Carvalho, L. M.; Bohrer, D.; Koshinsky, A.; Anal. Chim. Acta 2009, 648, 162.

104. Borba, R. P.; Coscione, A. R.; Figueiredo, B. R.; Zambello, F.; Quim. Nova 2009, 32, 970.

105. Duarte, J. C.; Luz, R. C. S.; Damos, F. S.; Tanaka, A. A.; Kubota, L. T.; Anal. Chim. Acta 2008, 612, 29.

106. Souza, A. L.; Santos, W. J. R.; Luz, R. C. S.; Damos, L. S.; Kubota, L. T.; Tanaka, A. A.; Tanaka, S. M. C. N.; Talanta 2008, 75, 333.

107. Santos, J. C. C.; Santos, E. B. G. N.; Korn, M.; Microchem. J. 2008, 90,1 .

108. Melchert, W. R.; Rocha, F. R. P.; Anal. Chim. Acta 2008, 616, 56.

109. Fortes, P. R.; Feres, M. A.; Zagatto, E. A. G.; Talanta 2008, 77, 571.

110. Infante, C. M. C.; Masini, J. C.; Rocha, F. R. P.; Anal. Bioanal. Chem. 2008, 391, 2931.

111. Infante, C. M. C.; Morales-Rubio, A.; de La Guardia, M.; Rocha, F. R. P.; Talanta 2008, 75, 1376.

112. Eberlin, M. N.; Silva, R. C.; Anal. Chim. Acta 2008, 620, 97.

113. Carletto, J. S.; Luciano, R. M.; Bedendo, G. C.; Carasek, E.; Anal. Chim. Acta 2009, 638, 45.

114. Menegário, A. A.; Smichowski, P.; Tonello, P. S.; Polla, G.; Oliveira, E. P.; Santelli, R. E.; Anal. Chim. Acta 2008, 625, 131.

115. Matos, G. D.; Reis, E. B.; Costa, A. C. S.; Ferreira, S. L. C.; Microchem. J. 2009, 92, 135.

116. Goveia, D.; Rosa, A. H.; Bellin, I. C.; Lobo, F. A.; Fraceto, L. F.; Roveda, J. A. F.; Romão, L. P. C.; Dias Filho, N. L.; Anal. Bioanal. Chem. 2008, 390, 1173.

117. Pimentel, P. M.; Anjos, M. J.; Melo, D. M. A.; Melo, M. A. F.; Gonçalves Jr., L. M.; Silva Jr., C. N.; Lopes, R. T.; Talanta 2008, 74, 1231.

118. Brum, D. M.; Cassella, R. J.; Pereira Netto, A. D.; Talanta 2008, 74, 1392.

119. Fernandes, R. N.; Reis, B. F.; Morales-Rubio, A.; de la Guardia, M.; J. Braz. Chem. Soc. 2009, 20, 1242.

120. Gonzáles, A. P. S.; Firmino, M. A.; Nomura, C. S.; Rocha, F. R. P.; Oliveira, P. V.; Gaubeur, I.; Anal. Chim. Acta 2009, 636, 198.

121. Moraes, F. C.; Mascaro, L. H.; Machado, S. A. S.; Brett, C. M. A.; Talanta 2009, 79, 1406.

122. Fontenele, A. P. G.; Pedrotti, J. J.; Fornaro, A.; Quim. Nova 2009, 32, 839.

123. Pacioni, N. L.; Occello, V. N. S.; Lazzarotto, M.; Veglia, A. V.; Anal. Chim. Acta 2008, 624, 133.

124. Maltez, H. F.; Borges, D. L. G.; Carasek, E.; Welz, B.; Curtius, A. J.; Talanta 2008, 74, 800.

125. DelValls, T. A.; Forja, J. M.; González-Mazo, E.; Gómez-Parra, A.; Trends Anal. Chem. 1998, 17, 171.
126. Machado, W.; Santelli, R. E.; Loureiro, D. D.; Oliveira, E. P.; Borges, A. C.; Ma, V. K.; Lacerda; J. Braz. Chem. Soc. 2008, $19,569$.

127. Luiz-Silva, W.; Machado, W.; Matos, R. H. R.; J. Braz. Chem. Soc. 2008, 19, 1490.

128. Hortellani, M. A.; Sarkis, J. E. S.; Abessa, D. M. S.; Sousa, E. C. P. M.; Quim. Nova 2008, 31, 10.

129. Silva, D. M. L.; Camargo, P. B.; Martinelli, L. A.; Lanças, F. M.; Pinto, J. S. S.; Avelar, W. E. P.; Quim. Nova 2008, 31, 214.

130. Garcia, C. A. B.; Barreto, M. S.; Passos, E. A.; Alves, J. P. H.; J. Braz. Chem. Soc. 2009, 20, 1334.

131. Cavalcante, R. M.; Lima, D. M.; Correia, L. M.; Nascimento, R. F.; Silveira, E. R.; Freire, G. S. S.; Viana, R. B.; Quim. Nova 2008, 31, 1371.

132. Hatje, V.; Costa, L. M.; Korn, M. G. A.; Cotrim, G.; J. Braz. Chem. Soc. 2009, 20, 846.

133. Lopes, W. L.; Santelli, R. E.; Oliveira, E. P.; Carvalho, M. F. B.; Bezerra, M. A.; Talanta 2009, 79, 1276.

134. Felizzola, J. F.; Wagener, A. L. R.; Almeida, A. C.; Lin, W. O.; Quim. Nova 2008, 31, 89.

135. Peakall, D.; Burger, J.; Ecotoxicol. Environ. Saf. 2003, 56, 110.

136. Bacon, J. R.; Davidson, C. M.; Analyst 2008, 133, 25.

137. Bevilacqua, J. E.; Silva, I. S.; Lichtig, J.; Masini, J. C.; Quim. Nova 2009, 32, 26.

138. Matos, G. D.; Arruda, M. A. Z.; Talanta 2008, 76, 475.

139. Mangrich, A. S.; Silva, L.; Pereira, B. F.; Messerschmidt, I.; J. Braz. Chem. Soc. 2009, 20, 294.

140. Araujo, R. G. O.; Welz, B.; Vignola, F.; Becker-Ross, H.; Talanta 2009, 80, 846 .

141. Torres, J. P. M.; Lailson-Brito, J.; Saldanha, G. C.; Dorneles, P.; Silva, C. E. A.; Malm, O.; Guimarães, J. R.; Azeredo, A.; Bastos, W. R.; Silva, V. M. F.; Martin, A. R.; Cláudio, L.; Markowitz, S.; J. Braz. Chem. Soc. 2009, 20, 1175.

142. Batista, B. L.; Rodrigues, J. L.; Nunes, J. A.; Tormen, L.; Curtius, A. J.; Barbosa Jr., F.; Talanta 2008, 76, 575.

143. Seixas, T. G.; Kehrig, H. A.; Di Benedito, A. P. M.; Souza, C. M. M.; Malm, O.; Moreira, I.; J. Braz. Chem. Soc. 2009, 20, 243.

144. Franzoi, A. C.; Dupont, J.; Spinelli, A.; Vieira, I. C.; Talanta 2009, 77, 1322.

145. Melo, L. C.; Salazar-Banda, G. R.; Machado, S. A. S.; Lima-Neto, P.; Souza D.; Correia, A. N.; Talanta 2009, 79, 1216.

146. Santos, M. C.; Wagner, M.; Wu, B.; Scheider, J.; Oehlmann, J.; Cadore, S.; Sabine-Becker, J.; Talanta 2009, 80, 428.

147. Almeida, M. D.; Marins, R. V.; Parquetti, H. H. M.; Lacerda, L. D.; J. Braz. Chem. Soc. 2008, 19, 1290.

148. Rocha, F. R.; Coelho, L. H. G.; Lopes, M. L. A.; Carvalho, L. R. F.; Silva, J. A. F.; Lago, C. L.; Gutz, I. G. R.; Talanta 2008, 76, 271.

149. Lima, F. M.; Pereira Netto, A. D.; J. Braz. Chem. Soc. 2009, 20, 488. 
150. Marques, L. F. C. S.; Arbilla, G.; Quiterio, S. L.; Machado, M. C. S.; J. Braz. Chem. Soc. 2009, 20, 518.

151. Rocha, G. O.; Lopes, W. A.; Pereira, P. A. P.; Vasconcellos, P. C.; Oliveira, F. S.; Carvalho, L. S.; Conceição, L. S.; De Andrade, J. B.; J. Braz. Chem. Soc. 2009, 20, 680.

152. Loyola, J.; Arbilla, G.; Quiterio, S. L. Escaleira, V.; Bellido, A. V.; J. Braz. Chem. Soc. 2009, 20, 1343.

153. Lourencetti, C.; Marchi, M. R. R.; Ribeiro, M. L.; Talanta 2008, $77,701$.

154. Raposo Jr., J. L.; Oliveira, S. R.; Caldas, N. M.; Gomes Neto, J. A.; Anal. Chim. Acta. 2008, 627, 198.

155. Matos, W. O.; Nóbrega, J. A.; Souza, G. B.; Nogueira, A. R. A.; Quim. Nova 2008, 31, 1450.

156. Oliveira, L. C.; Ribeiro, C. A.; Rosa, A. H.; Botero, W. G.; Rocha, J. C.; Romão, L. P. C.; Santos, A.; J. Braz. Chem. Soc. 2009, 20, 1135 .

157. Silva, R. P.; Masini, J. C.; Ribeiro, M. G.; Pedreira, W. P.; Cardoso, L. M. N.; Marchi, M. R. R.; Anal. Lett. 2008, 41, 2646.

158. Suchara, E. A.; Budziak, D.; Martendal, E.; Costa, L. L. F.; Carasek, E.; Anal. Chim. Acta 2008, 613, 169.

159. Souza, A. S. F.; Ferreira, E. M. M.; Cassella, R. J.; Anal. Chim. Acta 2008, 620, 89.

160. Pontes, F. V. M.; Carneiro, M. C.; Vaitsman, D. S.; Rocha, G. P.; Silva, L. I. D.; Neto, A. A.; Monteiro, M. I. C.; Anal. Chim. Acta 2009, 632, 284.

161. Macedo, S. M.; Jesus, R. M.; Garcia, K. S.; Hatje, V.; Queiroz, A. F.; Ferreira, S. L. C.; Talanta 2009, 80, 974.

162. Monteiro, M. R.; Ambrozin, A. R. P.; Lião, L. M.; Ferreira, A. G.; Talanta 2008, 77, 593.

163. Lobo, I. P.; Ferreira, S. L. C.; Cruz, R. S.; Quim. Nova 2009, 32, 1596.

164. Araujo, A. R. T. S.; Saraiva, M. L. M. F. S.; Lima, J. L. F. C.; Korn, M. G. A.; Anal. Chim. Acta 2008, 613, 177.

165. Lourenço, L. M.; Stradiotto, N. R.; Talanta 2009, 79, 92.

166. Rocha, D. Q.; Barros, D. K.; Costa, E. J. C.; Souza, K. S.; Passos, R. R.; Veiga Junior, V. F.; Chaar, J. S.; Quim. Nova 2008, 31, 1062-1066.

167. Monteiro, M. R.; Ambrozin, A. R. P.; Santos, M. S.; Boffo, E. F.; Pereira-Filho, E. R.; Lião, L. M.; Ferreira, A. G.; Talanta 2009, $78,660$.

168. Corgozinho, C. N. C.; Pasa, V. M. D.; Barbeira, P. J. S.; Talanta 2008, 76, 479.

169. Oliveira, I. K.; Carvalho, W. F.; Poppi, R. J.; Anal. Chim. Acta 2009, 642, 217.

170. Guarieiro, L. L. N.; Pinto, A. C.; Aguiar, P. F.; Ribeiro, N. M.; Quim. Nova 2009, 31, 421.

171. Bianchin, J.N.; Martendal, E.; Mior, R.; Alves, V. N.; Araújo, C.S.T.; Coelho, N. M. M.; Carasek, E.; Talanta 2009, 78, 333.

172. Alvesa, V. N.; Mosquetta, R.; Coelho, N. M. M.; Bianchin, J. N.; Roux, K. C. P.; Martendal, E.; Carasek, E.; Talanta, in press.
173. Saint'Pierre, T. D.; Maranhão, T. A.; Frescura, V. L.; Curtius, A. J.; Aucélio, R. Q.; Quim. Nova 2008, 31, 1626.

174. Jesus, A.; Silva, M. M.; Vale, M. G. R.; Talanta 2008, 74, 1378.

175. Chaves, E. S.; Saint'Pierre, T. D.; Santos, E. J.; Tormen, L.; Azzolin, V. L.; Bascunan, V. L. A. F.; Curtius, A. J.; J. Braz. Chem. Soc. 2008, 19, 856.

176. Souza, R. M.; Leocádio, L. G.; Silveira, C. L. P.; Anal. Lett. 2008, 41, 1615.

177. Castilho, M. S.; Stradiotto, N. R.; Talanta 2008, 74, 1630.

178. Amorim Filho, V. R.; Gomes Neto, J. A.; Anal. Lett. 2008, 41, 1547.

179. Polidorio, D. I.; Naozuka, J.; Vieira, E. C.; Oliveira, P. V.; Anal. Lett. 2008, 41, 1555.

180. Mello, P. A.; Giesbrecht, C. K.; Alencar, M. S.; Moreira, E. M.; Paniz, J. N. G.; Dressler, V. L.; Flores, E. M. M.; Anal. Lett. 2008, $41,1623$.

181. Flores, E. M. M.; Mesko, M. F.; Moraes, D. P.; Pereira, J. S. F.; Mello, P. A.; Barin, J. S.; Knapp, G.; Anal. Chem. 2008, 80, 1865.

182. Teixeira, L. S. G.; Chaves, T. J.; Guimarães, P. R. B.; Pontes, L. A. M.; Teixeira, J. S. R.; Anal. Chim. Acta 2009, 640, 29.

183. Aleme, H. G.; Costa, L. M.; Barbeira, P. J. S.; Talanta 2009, 78, 1422.

184. Fernandes, H. L.; Raimundo Jr.; I. M.; Pasquini, C.; Rohwedder, J. J. R.; Talanta 2008, 75, 804.

185. Bonfilio, R.; Tarley, C.R.T.; Pereira, G.R.; Salgado, H.R.N.; Araújo, M.B.; Talanta 2009, 80, 236.

186. Tsubone, C.; Garcia, P. L.; Gomes, F. P.; Kedor-Hackmann, E. R. M.; Santoro, M. I. R. M.; Anal. Lett. 2008, 41, 424.

187. Santoro, M. I. R. M.; Tsubone, C.; Gomes, F. P.; KedorHackmann, E. R. M.; Garcia, P. L.; Anal. Lett. 2008, 41, 2044.

188. Garcia, P. L.; Gomes, F. P.; Santoro, M. I. R. M; KedorHackmann, E. R. M.; Anal. Lett. 2008, 41, 1895.

189. Bergo, P. L. S.; Correa, J. M.; Nagem, T. J.; Augusti, R.; Nascentes, C. C.; J. Braz. Chem. Soc. 2009, 20, 348.

190. Netto, D. C.; Reis, R. M.; Mendes, C. B.; Gomes, P. C. F. L.; Martins, I.; Siqueira, M. E. P. B.; J. Braz. Chem. Soc. 2008, 19, 1201.

191. Mamani, M. C. V.; Amaya-Farfan, J.; Reyes, F. G. R.; Silva, J. A. F.; Rath, S.; Talanta 2009, 76, 1006.

192. Faria, A. F.; Souza, M. V. N.; Oliveira, M. A. L.; J. Braz. Chem. Soc. 2008, 19, 389.

193. Silva, R. P.; Lima, A. W. O.; Serrano, S. H. P.; Anal. Chim. Acta 2008, 612, 89.

194. Skeika, T.; Faria, M. F.; Nagata, N.; Pessoa, C. A.; J. Braz. Chem. Soc. 2008, 19, 762.

195. Reis, A. P.; Tarley, C. R. T.; Kubota, L. T.; J. Braz. Chem. Soc. 2008, 19, 1567.

196. Medeiros, R. A.; Carvalho, A. E.; Rocha-Filho, R. C.; Mazol, L. H.; Fatibello-Filho, O.; Talanta 2009, 78, 748.

197. Lourenção, B. C.; Medeiros, R. A.; Carvalho, A. E.; Rocha-Filho, R. C.; Fatibello-Filho, O.; Talanta 2008, 76, 685. 
198. Cervini, P.; Cavalheiro, E. T. G.; J. Braz. Chem. Soc. 2008, 19, 836.

199. Semaan, F. S.; Cavalheiro, E. T. G.; Anal. Lett. 2009, 42, 1119.

200. Sotomayor, M. D. P. T.; Sigoli, A.; Lanza, M. R. V.; Tanaka, A. A.; Kubota, L. T.; J. Braz. Chem. Soc. 2008, 19, 734.

201. Santini, A. O.; Pezza, H. R.; Oliveira, J. E.; Pezza, L.; J. Braz. Chem. Soc. 2008, 19, 162.

202. Santini, A. O.; Pezza, H. R.; Sequinel, R.; Rufino, J. L.; Pezza, L.; J. Braz. Chem. Soc. 2009, 20, 64.

203. Hoffman, A. A.; Dias, S. L. P.; Rodrigues, J. R.; Pavan, F. A.; Benvenutti, E. V.; Lima, E. C.; J. Braz. Chem. Soc. 2008, 19, 943.

204. Cottica, S. M.; Nozaki, J.; Nakatani, H. S.; Oliveira, C. C.; Souza, N. E.; Visentainer, J. V.; J. Braz. Chem. Soc. 2009, 20, 496.

205. Franzoi, A. C.; Migowski, P.; Dupont, J.; Vieira, I. C.; Anal. Chim. Acta 2009, 639, 90.

206. Franzoi, A. C.; Peralta, R. A.; Neves, A.; Vieira, I. C.; Talanta 2009, 78, 221.

207. Moreno, A. H.; Salgado, H. R. N.; Anal. Lett. 2008, 41, 2143.

208. Dias, C. L.; Bergold, A. M.; Froehlich, P. E.; Anal. Lett. 2009, 42, 1900.

209. Los Weinert, P.; Pezza, L.; Pezza, H. R.; Quim. Nova 2008, 31, 1112.

210. Trevisan, M. G.; Poppi, R. J.; Talanta 2008, 75, 1021.

211. Rossignoli, P.; Pontarolo, R.; Correr, C. J.; Cordeiro, G.; PeraltaZamora, P.; Quim. Nova 2008, 31, 1285.

212. Silva, M. J.; Anjos, E. V.; Honorato, R. S.; Pimentel, M. F.; Paim, A. P. S.; Anal. Chim. Acta 2008, 629, 98.

213. Grunhut, M.; Centurión, M. E.; Fragoso, W. D.; Almeida, L. F.; Araújo, M. C. U.; Fernández-Band, B.; Talanta 2008, 75, 950.

214. Sanchez, M. A.; Rocha, F. R. P.; Anal. Lett. 2008, 41, 1579.

215. Oliveira, G. G.; Janegitz, B. C.; Batistão, M. B.; Salami, F. H.; Fatibello-Filho, O.; Leite, O. D.; Quim. Nova 2009, 32, 1755.

216. Pacheco, W. F.; Batalha, J. A. L.; Oliveira, C. C.; Aucélio, R. Q.; Talanta 2008, 74, 1442.

217. Finete, V. L. M.; Arissawa, M.; Aucélio, R. Q.; J. Braz. Chem. Soc. 2008, 19, 1418.

218. Marques, F. F. C.; de Souza, C. F.; Figueiredo, F. S.; Aucélio, R. Q.; Anal. Lett. 2008, 41, 1648.

219. Schmidt Jr., E.; Melchert, W. R.; Rocha, F. R. P.; J. Braz. Chem. Soc. 2009, 20, 236.

220. Suarez, W. T.; Bonifácio, V. G.; Madi, A. A.; Fatibello-Filho, O.; Anal. Lett. 2009, 42, 973 .

221. Santos, W. T. P.; Gimenes, D. T.; Almeida, E. G. N.; Eiras, S. P.; Albuquerque, Y. D. T.; Richter, E. M.; J. Braz. Chem. Soc. 2009, 20, 1249.

222. Silveira, G.; Tarley, C. R. T.; Quim. Nova 2008, 31, 1653.

223. Felix, F. S.; Brett, C. M. A.; Angnes, L.; Talanta 2008, 76, 128.

224. Semaan, F. S.; Nogueira, P. A.; Cavalheiro, E. T. G.; Anal. Lett. 2008, 41, 66 .

225. Faria, A. M.; Collins, C. H.; Jardim, I. C. S. F.; J. Braz. Chem. Soc. 2009, 20, 1385.
226. Teixeira-Neto, E.; Teixeira-Neto, A. A.; Quim. Nova 2009, 32, 809.

227. Vidotti, M.; Torresi, S. I. C.; J. Braz. Chem. Soc. 2008, 19, 1248.

228. Pereira, E.; Oliveira, L. C. A.; Vallone, A.; Sapag, K.; Pereira, M.; Quim. Nova 2008, 31, 1296.

229. Cardoso, C. L.; Moraes, M. C.; Guido, R. V. C.; Oliva, G.; Andricopulo, A. D.; Wainer, I. W.; Cass, Q. B.; Analyst 2008, 133, 93.

230. Vaz, F. A. S.; Castro, P. M.; Molina, C.; Ribeiro, S. J. L.; Polachini, F. C.; Messaddeq, Y.; Nunes, A. P.; Oliveira, M. A. L.; Talanta 2008, 76, 226.

231. Collins, C. H.; Silva, C. R.; Faria, A. M.; Collins, K. E.; Jardim, I. C. S. F.; J. Braz. Chem. Soc. 2009, 20, 604.

232. Pilau, E. J.; Silva, R. G. C.; Jardim, I. C. F. S.; Augusto, F.; J. Braz. Chem. Soc. 2008, 19, 1136.

233. Silva, G. M.; Lemos, S. G.; Pocrifka, L. A.; Marreto, P. D.; Rosario, A. V.; Pereira, E. C.; Anal. Chim. Acta 2008, 616, 36.

234. Quintino, M. S. M.; Araki, K.; Toma, H. E.; Angnes, L.; Talanta 2008, 74, 730 .

235. Crespilho, F. N.; Ghica, M. E.; Gouveia-Caridade, C.; Oliveira Jr., O. N.; Brett, C. M. A.; Talanta 2009, 76, 922.

236. Moreira, L. F.; Lanza, M. R. V.; Tanaka, A. A.; Sotomayor, M. D. P.; Analyst 2009, 134, 1453.

237. Rippel, M. M.; Bragança, F. C.; Quim. Nova 2009, 32, 818.

238. Galembeck, F.; Barbosa, C. A. S.; Sousa, R. A.; Quim. Nova 2009, 32, 571.

239. Cordeiro, G. C.; Toledo Filho, R. D.; Fairbairn, E. M. R.; Quim. Nova 2009, 32, 82.

240. Pauliukaite, R.; Ghica, M. E.; Fatibello-Filho, O.; Brett, C. M. A.; Anal. Chem. 2009, 81, 5364.

241. Gonçalves, V. R.; Massafera, M. P.; Benedetti, T. M.; Moore, D. G.; Torresi, S. I. C.; Torresi, R. M.; J. Braz. Chem. Soc. 2009, 20, 663 .

242. Rippel, M. M.; Galembeck, F.; J. Braz. Chem. Soc. 2009, 20, 1024.

243. Cadore, S.; Matoso, E.; Santos, M.; Quim. Nova 2008, 31, 1533. 244. Matoso, E.; Cadore, S.; J. Braz. Chem. Soc. 2008, 19, 1284.

245. Melquiades, F. L.; Ferreira, D. D.; Appoloni, C. R.; Lopes, F.; Lonni, A. G.; Oliveira, F. M.; Duarte, J. C.; Anal. Chim. Acta 2008, 613, 135.

246. Eguiluz, K. I. B.; Salazar-Banda, G. R.; Funes-Huacca, M. E.; Alberice, J. V.; Carrilho, E.; Machado, S. A. S.; Avaca, L. A.; Analyst 2009, 134, 314.

247. Gaona-Galdos, A. A.; García, P. L.; Aurora-Prado, M. S.; Santoro, M. I. R. M.; Kedor-Hackmann, E. R. M.; Talanta 2008, 77, 673.

248. Guimarães, I. C.; Rezende, C. C.; Silva, J. A. F., Jesus, D. P.; Talanta 2009, 78, 1436.

249. Silvério, F. O.; Barbosa, L. C. A.; Maltha, C. R. A.; Piló-Veloso, D.; Anal. Chim. Acta 2009, 643, 108.

250. Cervini, P.; Cavalheiro, E. T. G.; Anal. Lett. 2008, 41, 1867.

251. Cervini, P.; Cavalheiro, E. T. G.; Anal. Lett. 2009, 42, 1940. 
252. Tarley, C. R. T.; Silveira, G.; Santos, W. N. L.; Matos, G. D.; Silva, E. G. P.; Bezerra, M. A.; Miró, M.; Ferreira, S. L. C.; Microchem. J. 2009, 92, 58.

253. Kiralj, R.; Ferreira, M. M. C.; J. Braz. Chem. Soc. 2009, 20, 770.

254. Carvalho, P. C.; Cociorva, D.; Wong, C. C. L.; Carvalho, M. G. C.; Barbosa, V. C.; Yates III, J. R.; Anal. Chem. 2009, 81, 1996.

255. Bezerra, M. A.; Santelli, R. E.; Oliveira, E. P.; Villar, L. S.; Escaleira, L. M.; Talanta 2008, 76, 965.

256. Bueno, L.; Quim. Nova 2008, 31, 585.

257. Soares, P. K.; Bruns, R. E.; Scarminio, I. S.; Anal. Chim. Acta 2008, 613, 48.

258. Paim, C. S.; Gonçalves, H.; Lange, A.; Miron, D.; Steppe, M.; Anal. Lett. 2008, 41, 571

259. Souza, J. M. O.; Tarley, C. R. T.; Anal. Lett. 2008, 41, 2465.

260. Uliana, C. V.; Riccardi, C. S.; Tognolli, J. O.; Yamanaka, H.; J. Braz. Chem. Soc. 2008, 19, 782.

261. Santos, A. C. V.; Masini, J. C.; Microchem. J. 2009, 93, 110.

262. Lara, P. C. P.; Silveira, J. N.; Borges Neto, W.; Silva, J. B. B.; Anal. Lett. 2009, 42, 923.

263. Andrade, M. F.; Souza, D. J. P.; Silva, J. B. P.; Paim, A. P. S.; Quím. Nova 2008, 31, 296.

264. Santos, J. S.; Santos, M. L. P.; Oliveira, E.; Quim. Nova 2008, $31,1107$.

265. Godinho, M. S.; Pereira, R. O.; Ribeiro, K. O.; Schimidt, F.; Oliveira, A. E.; Oliveira, S. B.; Quim. Nova 2008, 31, 1485.

266. Froes, R. E. S.; Borges Neto, W.; Naveira, R. L. P.; Silva, N. C.; Nascentes, C. C.; Silva, J. B. B.; Microchem. J. 2009, 92, 68.

267. Santos, J. S.; Santos, N. S.; Santos, M. L. P.; Santos, S. N.; Lacerda, J. J. J.; J. Braz. Chem. Soc. 2008, 19, 502.

268. Reche, R. V.; Franco, D. W.; Quim. Nova 2009, 32, 332.

269. Panero, F. S.; Silva, H. E. B.; Microchem. J. 2008, 88, 194.

270. Zimmermann, C. M.; Guimarães, O. M.; Peralta-Zamora, P. G.; Quim. Nova 2008, 31, 1727.

271. Pontes, M. J. C.; Cortez, J.; Galvão, R. K. H.; Pasquini, C.; Araújo, M. C. U.; Coelho, R. M.; Chiba, M. K.; Abreu, M. F.; Madari, B. E.; Anal. Chim. Acta 2009, 642, 12.

272. Risticevic, S.; Carasek, E.; Pawliszyn, J.; Anal. Chim. Acta 2008, $617,72$.

273. Schiozer, A. L.; Março, P. H.; Barata, L. E. S.; Poppi, R. J.; Anal. Lett. 2008, 41, 1592.

274. Moreira, E. D. T.; Pontes, M. J. C.; Galvão, R. K. H.; Araújo, M. C. U.; Talanta 2009, 79, 1260.

275. Pereira, C. F.; Pimentel, M. F.; Galvão, R. K. H.; Honorato, F. A.; Stragevitch, L.; Martins, M. N.; Anal. Chim. Acta 2008, 611, 41.

276. Valderrama, P.; Poppi, R. J.; Anal. Chim. Acta 2009, 623, 38.

277. Trevisan, M. G.; Garcia, C. M.; Schuchardt, U.; Poppi, R. J.; Talanta 2008, 74, 971.

278. Godoy, L. A. F.; Ferreira, E. C.; Pedroso, M. P.; Fidélis, C. H. V.; Augusto, F.; Poppi, R. J.; Anal. Lett. 2008, 41, 1603.

279. Mello, C.; Sevéri, E.; Ricci, E.; Marangoni, A.; Coelho, L.; Ribeiro, D.; Poppi, R. J.; J. Braz. Chem. Soc. 2008, 19, 29.
280. Hernández, N.; Talavera, I.; Biscay, R. J.; Porro, D.; Ferreira, M. M. C.; Anal. Chim. Acta 2009, 642, 110.

281. Alves, J. C. L.; Poppi, R. J.; Anal. Chim. Acta 2009, 642, 212.

282. Valderrama, P.; Poppi, R. J.; Anal. Chim. Acta 2009, 651, 31.

283. Martins, V. L.; Galvão, R. K. H.; Araújo, M. C. U.; Gaião, E. N.; J. Braz. Chem. Soc. 2009, 20, 1561.

284. Gaião, E. N.; Santos, S. R. B.; Santos, V. B.; Nascimento, E. C. L.; Lima, R. S.; Araújo, M. C. U.; Talanta 2008, 75, 792.

285. Veras, G.; Silva, E. C.; Lyra, W. S.; Soares, S. F. C.; Guerreiro, T. B.; Santos, S. R. B.; Talanta 2009, 77, 1155.

286. Lyra, W. S.; Santos, V. B.; Dionízio, A. G. G.; Martins, V. L.; Almeida, L. F.; Gaião, E. N.; Diniz, P. H. G. D.; Silva, E. C.; Araújo, M. C. U.; Talanta 2009, 77, 1584.

287. Gomes, M. S.; Trevisan, L. C.; Nóbrega, J. A.; Kamogawa, M. Y.; Quim. Nova 2008, 31, 1577.

288. Martínez-Cisneros, C. S.; Rocha, Z.; Ferreira, M.; Valdés, F.; Seabra, A.; Góngora-Rubio, M.; Alonso-Chamarro, J.; Anal. Chem. 2009, 81, 7448.

289. Ferreira, H. E. A.; Daniel, D.; Bertotti, M.; Richter, E. M.; J. Braz. Chem. Soc. 2008, 19, 1538.

290. Silva, R. A. B.; Almeida, E. G. N.; Rabelo, A. C.; Silva, A. T. C.; Ferreira, L. F.; Richter, E. M.; J. Braz. Chem. Soc. 2009, 20, 1235.

291. Coutinho, C. F. B.; Coutinho, L. F. M.; Lanças, F. M.; Câmara, C. A. P.; Nixdorf, S. L.; Mazo, L. H.; J. Braz. Chem. Soc. 2008, 19, 131.

292. Pereira, C. F.; Gonzaga, F. B.; Pasquini, C.; Anal. Chem. 2008, $80,3175$.

293. Santos, A. C. V.; Masini, J. C.; Talanta 2009, 77, 1081.

294. Rigobello-Masini, M.; Penteado, J. C. P.; Liria, C. W.; Miranda, M. T. M.; Masini, J. C.; Anal. Chim. Acta 2008, 628, 123.

295. Kamogawa, M. Y.; Teixeira, M. A.; Quim. Nova 2009, 32, 1644.

296. Fortes, P. R.; Feres, M. A.; Sasaki, M. K.; Alves, E. R.; Zagatto, E. A. G.; Prior, J. A. V.; Santos, J. L. M.; Lima, J. L. F. C.; Talanta 2009, 79, 978.

297. Assunção, N. A.; Miranda, C. E. S.; Lanças, F. M.; Rosias, M. F. G. G.; Carrilho, E.; J. Braz. Chem. Soc. 2008, 19, 1165.

298. Infante, C. M. C.; Rocha, F. R. P.; Microchem. J. 2008, $90,19$.

299. Melchert, W. R.; Rocha, F. R. P.; Raimundo Jr., I. M.; Reis, B. F.; Quim. Nova 2008, 31, 427.

300. Galo, A. L.; Colombo, M. F.; Quim. Nova 2009, 32, 488.

301. Sousa, E. T.; Oliveira, F. S.; Alves, A. C.; Andrade, J. B.; J. Braz. Chem. Soc. 2009, 20, 259.

302. Pinto, J. J. S.; Lanças, F. M.; J. Braz. Chem. Soc. 2009, $20,913$.

303. Catalani, L. H.; Bolzani, V. S.; J. Braz. Chem. Soc. 2009, 20(5), iv.

Received: November 6, 2009 Web Release Date: December 3, 2009

FAPESP helped in meeting the publication costs of this article. 